\title{
Strategy to Identify Improved $N$-Terminal Modifications for Supramolecular Phenylalanine-Derived Hydrogelators
}

\author{
Brittany L. Abraham, Wathsala Liyanage, and Bradley L. Nilsson* \\ Department of Chemistry, University of Rochester, Rochester, NY 14627-0216, USA. \\ E-mail: bradley.nilsson@,rochester.edu \\ Fax: +1 585 276-0205; Tel. +1 585 276-3053
}

SUPPORTING INFORMATION

\section{Contents:}

Synthesis of $\boldsymbol{N}$-terminal protected $\boldsymbol{p}$-NO $\mathrm{N}_{2}$-Phe derivatives (2-6).................................page 2

Synthesis of 1-Nap-X-Phe derivatives (10-12). page 5

Figure S1. ${ }^{1} \mathrm{H}$ NMR spectrum of 2-Nap-4-NO 2 -Phe (2)..... page 8

Figure S2. ${ }^{13} \mathrm{C}$ NMR spectrum of 2-Nap-4-NO $\mathrm{NO}_{2}-\mathrm{Phe}(2)$ page 9

Figure S3. ${ }^{1} \mathrm{H}$ NMR spectrum of 1-Nap-4-NO $2-\mathrm{Phe}(3)$. page 10

Figure S4. ${ }^{13} \mathrm{C}$ NMR spectrum of 1-Nap-4-NO 2 -Phe (3) .................................................page 11

Figure S5. ${ }^{1} \mathrm{H}$ NMR spectrum of $\mathrm{Cy}-4-\mathrm{NO}_{2}-\mathrm{Phe}(4)$..... page 12

Figure S6. ${ }^{13} \mathrm{C}$ NMR spectrum of $\mathrm{Cy}-4-\mathrm{NO}_{2}-\mathrm{Phe}(4)$ page 13

Figure S7. ${ }^{1} \mathrm{H}$ NMR spectrum of $\mathrm{Hex}-4-\mathrm{NO}_{2}-\mathrm{Phe}(\mathbf{5})$. page 14

Figure S8. ${ }^{13} \mathrm{C}$ NMR spectrum of $\mathrm{Hex}-4-\mathrm{NO}_{2}-\mathrm{Phe}(5)$ page 15

Figure S9. ${ }^{1} \mathrm{H}$ NMR spectrum of $\mathrm{Pyr}-4-\mathrm{NO}_{2}-\mathrm{Phe}(6)$... page 16

Figure S10. ${ }^{13} \mathrm{C}$ NMR spectrum of $\mathrm{Pyr}-4-\mathrm{NO}_{2}-\mathrm{Phe}(\mathbf{6})$ page 17

Figure S11. ${ }^{1} \mathrm{H}$ NMR spectrum of 1-Nap-Phe (10). .page 18

Figure S12. ${ }^{13} \mathrm{C}$ NMR spectrum of 1-Nap-Phe (10). page 19

Figure S13. ${ }^{1} \mathrm{H}$ NMR spectrum of 1-Nap-3F-Phe (11). .page 20

Figure S14. ${ }^{13} \mathrm{C}$ NMR spectrum of 1-Nap-3F-Phe (11) page 21

Figure S15. ${ }^{19} \mathrm{~F}$ NMR spectrum of 1-Nap-3F-Phe (11) page 22

Figure S16. ${ }^{1} \mathrm{H}$ NMR spectrum of $1-\mathrm{Nap}-\mathrm{F}_{5}-\mathrm{Phe}$ (12). page 23

Figure S17. ${ }^{13} \mathrm{C}$ NMR spectrum of $1-\mathrm{Nap}-\mathrm{F}_{5}-\mathrm{Phe}(\mathbf{1 2})$ .page 24

Figure S18. ${ }^{19} \mathrm{~F}$ NMR spectrum of $1-\mathrm{Nap}-\mathrm{F}_{5}-\mathrm{Phe}$ (12) page 25

Figure S19. Digital image of 1-Nap- $\mathrm{F}_{5}-\mathrm{Phe}(12)$ on rheometer.. .page 26

Figure S20. Strain sweep data for hydrogels of compounds 8-9. page 27

Figure S21. Strain sweep data for hydrogels of compounds 10-12 page 27

Figure S22. Frequency sweep data for hydrogels of compounds 8-9. page 28

Figure S23. Frequency sweep data for hydrogels of compounds 10-12 .page 28

Figure S24. Digital image of hydrogels of 9 and 12 prepared via DMSO method...............page 29

Figure S25. Digital image of hydrogels of 9 and 12 prepared via GdL method. .page 29

Figure S26. Digital image of hydrogels of 8 and 11 prepared via GdL method. page 30 


\section{Synthesis of $N$-terminal protected $p$-NO2-Phe derivatives}

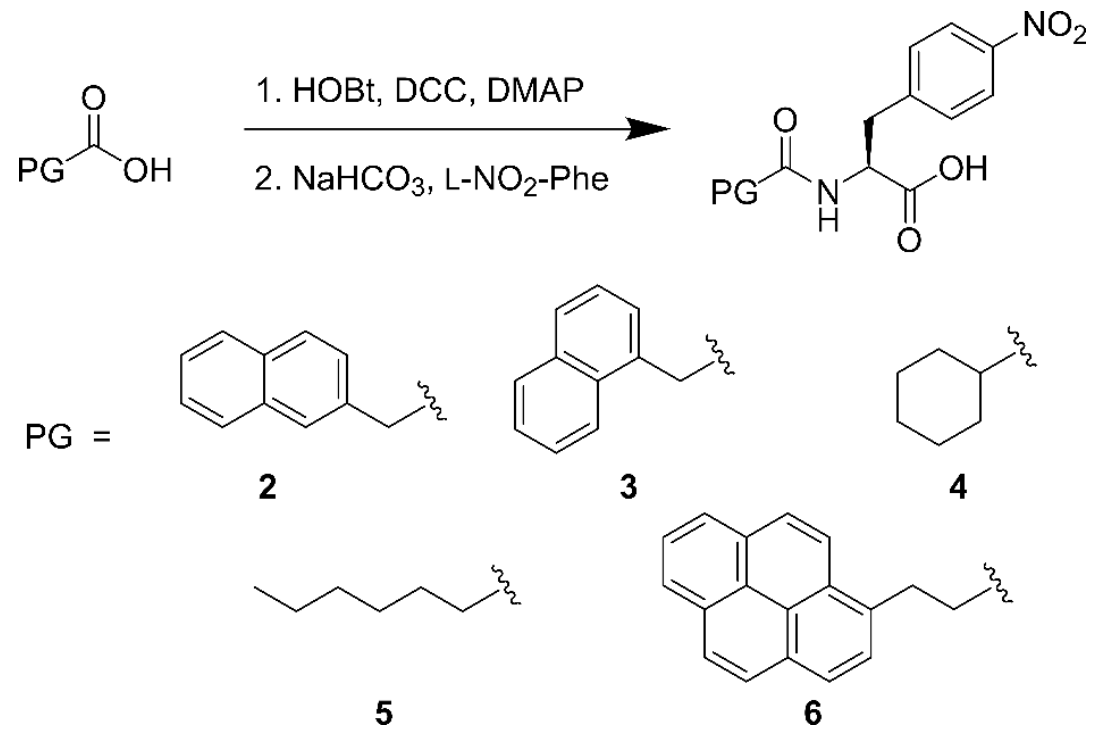

The coupling of 4-nitro-L-phenylalanine and the various $N$-terminal protecting groups was done via the same procedure as shown in the above Scheme for compounds 2-6 (preparation of compound $\mathbf{2}$ is presented below as a representative example).<smiles>O=C(Cc1ccc2ccccc2c1)N[C@@H](Cc1ccc([N+](=O)[O-])cc1)C(=O)O</smiles>

\section{2-Nap-4-NO2-Phe (2):}

A solution of 2-naphthaleneacetic acid (500 mg, $2.69 \mathrm{mmol})$ and $N$-hydroxybenzotriazole (HOBt) (364 mg, $2.69 \mathrm{mmol})$ in dichloromethane (DCM) $(10 \mathrm{~mL})$ was treated at room temperature with $N, N^{\prime}$-dicyclohexylcarbodiimide (DCC) $(610 \mathrm{mg}, 2.96 \mathrm{mmol})$ and 4-dimethylaminopyridine (DMAP) $(33 \mathrm{mg}, 0.27 \mathrm{mmol}$ ). After stirring at room temperature for $30 \mathrm{~min}$, the resulting solid precipitate was removed by filtration. The filtrate was concentrated in vacuo and the crude residue was used in the next reaction without further purification.

A solution of 4-nitro-L-phenylalanine $(565 \mathrm{mg}, 2.69 \mathrm{mmol})$ and sodium bicarbonate $\left(\mathrm{NaHCO}_{3}\right)$ (452 mg, $5.38 \mathrm{mmol}$ ) in water was added to a solution of the above crude residue in acetone/ethanol $(1: 1,20 \mathrm{~mL})$ and stirred for 24 hours at room temperature. The mixture was concentrated by rotary evaporation, then water was added and the precipitate was removed by filtration. The filtrate was acidified to $\mathrm{pH} \sim 3$ and the resulting white precipitate was obtained by filtration, washed with $\mathrm{H}_{2} \mathrm{O}$, and then dried in vacuo. The desired product 2 was obtained as a white powder (662 $\mathrm{mg}, 1.75$ mmol, 65\% yield). 
${ }^{1} \mathrm{H}$ NMR (500 MHz, DMSO-d $): \delta 12.89$ (broad s, 1H), $8.51(\mathrm{~d}, \mathrm{~J}=9 \mathrm{~Hz}, 2 \mathrm{H}), 7.98$ (d, J = $9 \mathrm{~Hz}$, $2 \mathrm{H}), 7.84(\mathrm{~d}, \mathrm{~J}=9 \mathrm{~Hz}, 1 \mathrm{H}), 7.76-7.73(\mathrm{~m}, 2 \mathrm{H}), 7.6(\mathrm{~s}, 1 \mathrm{H}), 7.50-7.30(\mathrm{~m}, 4 \mathrm{H}), 7.26(\mathrm{~d}, \mathrm{~J}=11 \mathrm{~Hz}$, $1 \mathrm{H}), 4.60-4.52(\mathrm{~m}, 1 \mathrm{H}), 3.60-3.51(\mathrm{~m}, 2 \mathrm{H}), 3.24-3.22(\mathrm{~m}, 1 \mathrm{H}) \mathrm{ppm} ;{ }^{13} \mathrm{C}$ NMR $(125 \mathrm{MHz}$, DMSO$\left.\mathrm{d}_{6}\right): \delta 173.0,170.5,146.6,146.4,134.2,133.3,132.2,130.9,128.0,127.9,127.7,127.6,126.5$, 126.0, 123.5, 53.2, 42.6, $37.0 \mathrm{ppm}$; HRMS (ESI-TOF) $(\mathrm{m} / \mathrm{z}) 401.1111$ (401.1113 calcd for $\left.\mathrm{C}_{21} \mathrm{H}_{19} \mathrm{~N}_{2} \mathrm{O}_{5}[\mathrm{MNa}]^{+}\right)$.<smiles>O=C(Cc1cccc2ccccc12)NC(Cc1ccc([N+](=O)[O-])cc1)C(=O)O</smiles>

\section{1-Nap-4-NO2-Phe (3):}

The product was prepared by following the same procedure described for the synthesis of $\mathbf{2}$, with 1-naphthaleneacetic acid (500 mg, $2.69 \mathrm{mmol})$ in place of 2-naphthaleneacetic acid. The desired product 3 was obtained as a white powder (713 $\mathrm{mg}, 1.88 \mathrm{mmol}, 70 \%$ yield).

${ }^{1} \mathrm{H}$ NMR (500 MHz, DMSO-d $): \delta 12.50$ (broad s, $\left.1 \mathrm{H}\right), 8.58(\mathrm{~d}, \mathrm{~J}=8.5 \mathrm{~Hz}, 1 \mathrm{H}), 8.06(\mathrm{~d}, \mathrm{~J}=8.5$ $\mathrm{Hz}, 2 \mathrm{H}), 7.93-7.90(\mathrm{~m}, 2 \mathrm{H}), 7.81(\mathrm{~d}, \mathrm{~J}=8 \mathrm{~Hz}, 1 \mathrm{H}), 7.51-7.39(\mathrm{~m}, 6 \mathrm{H}), 7.34(\mathrm{~d}, \mathrm{~J}=7 \mathrm{~Hz}, 1 \mathrm{H})$, 4.62-4.57 (m, 1H), 4.16 (s, 2H), 3.93-3.19 (m, 1H), 3.07-3.02 (m, 1H) ppm; ${ }^{13} \mathrm{C}$ NMR (125 MHz, DMSO-d 6 ): $\delta 172.6,171.2,170.0,146.1,146.0,133.2,132.4,131.7,130.4,128.3,127.7,127.0$, 125.7, 125.4, 125.3, 124.2, 123.1, 53.2, 36.1 ppm; HRMS (ESI-TOF) (m/z) $401.1111(401.1113$ calcd for $\mathrm{C}_{21} \mathrm{H}_{19} \mathrm{~N}_{2} \mathrm{O}_{5}[\mathrm{MNa}]^{+}$).<smiles>O=C(NC(Cc1ccc([N+](=O)[O-])cc1)C(=O)O)C1CCCCC1</smiles>

\section{Cy-4-NO2-Phe (4):}

The product was prepared by following the same procedure described for the synthesis of $\mathbf{2}$, with cyclohexane carboxylic acid $(500 \mathrm{mg}, 3.90 \mathrm{mmol})$ in place of 2-naphthaleneacetic acid. The desired product 4 was obtained as a white powder (461 mg, $1.44 \mathrm{mmol}, 37 \%$ yield).

${ }^{1} \mathrm{H}$ NMR (500 MHz, DMSO-d 6 ): $\delta 12.73$ (broad s, 1H), $8.13(\mathrm{~d}, \mathrm{~J}=11 \mathrm{~Hz}), 8.02(\mathrm{~d}, \mathrm{~J}=11 \mathrm{~Hz}$, $1 \mathrm{H}), 7.48(\mathrm{~d}, \mathrm{~J}=11 \mathrm{~Hz}, 2 \mathrm{H}) 4.47-4.48(\mathrm{~m}, 1 \mathrm{H}), 3.21-3.18(\mathrm{~m}, 1 \mathrm{H}), 3.00-2.96(\mathrm{~m}, 1 \mathrm{H}), 2.07(\mathrm{~s}$, 1H), $1.59-1.46(\mathrm{~m}, 4 \mathrm{H}), 1.24-1.12(\mathrm{~m}, 5 \mathrm{H}) \mathrm{ppm} ;{ }^{13} \mathrm{C}$ NMR (125 MHz, DMSO-d 6 ): $\delta 175.1,172.8$, 146.3, 146.2, 130.5, 123.1, 52.4, 43.6, 36.4, 29.1, 28.9, 25.2, $25.1 \mathrm{ppm}$; HRMS (ESI-TOF) (m/z) 343.1267 (343.1270 calcd for $\left.\mathrm{C}_{16} \mathrm{H}_{21} \mathrm{~N}_{2} \mathrm{O}_{5}[\mathrm{MNa}]^{+}\right)$. 
<smiles>CCCCCCC(=O)N[C@@H](Cc1ccc([N+](=O)[O-])cc1)C(=O)O</smiles>

\section{Hex-4-NO2-Phe (5):}

The product was prepared by following the same procedure described for the synthesis of $\mathbf{2}$, with heptanoic acid (500 mg, $3.84 \mathrm{mmol}$ ) in place of 2-naphthaleneacetic acid. The desired product 5 was obtained as a white powder (571 $\mathrm{mg}, 1.77 \mathrm{mmol}, 46 \%$ yield $)$.

${ }^{1} \mathrm{H}$ NMR (500 MHz, DMSO-d $\left.{ }_{6}\right): \delta 12.79$ (broad s, 1H), 8.16-8.13 (m, 3H), $7.51(\mathrm{~d}, \mathrm{~J}=8 \mathrm{~Hz}, 2 \mathrm{H})$, 4.56-4.51 (m, 1H), 3.24-3.21 (m, 1H), 2.99-2.94 (m, 1H), 2.02-1.99 (m, 2H), 1.35-1.32 (m, 2H), 1.16-1.11 (m, 4H), 1.10-0.99 (m, 2H), 0.81-0.78 (m, 3H) ppm; ${ }^{13} \mathrm{C}$ NMR (125 MHz, DMSO-d 6 ): $\delta 172.8,172.1,146.3,130.5,123.1,52.4,36.4,35.0,30.9,28.0,25.1,22.0,13.7$ ppm; HRMS (ESITOF) (m/z) 345.1422 (345.1426 calcd for $\left.\mathrm{C}_{16} \mathrm{H}_{23} \mathrm{~N}_{2} \mathrm{O}_{5}[\mathrm{MNa}]^{+}\right)$.<smiles>O=C(CCc1ccc2ccc3cccc4ccc1c2c34)NC(Cc1ccc([N+](=O)[O-])cc1)C(=O)O</smiles>

\section{Pyr-4-NO2-Phe (6):}

The product was prepared by following the same procedure described for the synthesis of $\mathbf{2}$, with 1-pyrenebutyric acid $(500 \mathrm{mg}, 1.73 \mathrm{mmol})$ in place of 2-naphthaleneacetic acid. The desired product 6 was obtained as a yellow powder (400 mg, $0.86 \mathrm{mmol}, 50 \%$ yield).

${ }^{1} \mathrm{H}$ NMR (500 MHz, DMSO-d 6 ): $\delta 12.84$ (broad s, 1H), 8.40-8.27 (m, 4H), 8.19-8.11 (m, 3H), 8.07-8.04 (m, 4H), 7.85-7.82 (m, 1H), 7.55-7.50 (m, 2H), 4.63-4.62 (m, 1H), 4.07-4.04 (m, 1H), 3.27-2.97 (m, 4H), 2.21-2.20 (m, 2H), 1.99-1.91 (m, 3H), 1.18-1.17 (m, 1H) ppm; ${ }^{13} \mathrm{C}$ NMR (125 MHz, DMSO-d $): \delta 172.9,172.1,146.3,146.2,136.5,130.9,130.5,130.4,129.3,128.1,127.4$, $127.2,126.5,126.1,124.9,124.8,124.2,124.2,123.2,52.9,36.6,34.8,32.1,27.6$ ppm; HRMS (ESI-TOF) (m/z) 469.1375 (469.1763 calcd for $\left.\mathrm{C}_{28} \mathrm{H}_{25} \mathrm{~N}_{2} \mathrm{O}_{2}\left[\mathrm{MNa}^{+}\right]\right)$. 


\section{Synthesis of 1-Nap-X-Phe derivatives}<smiles>[R]CC(N)C(=O)O</smiles>
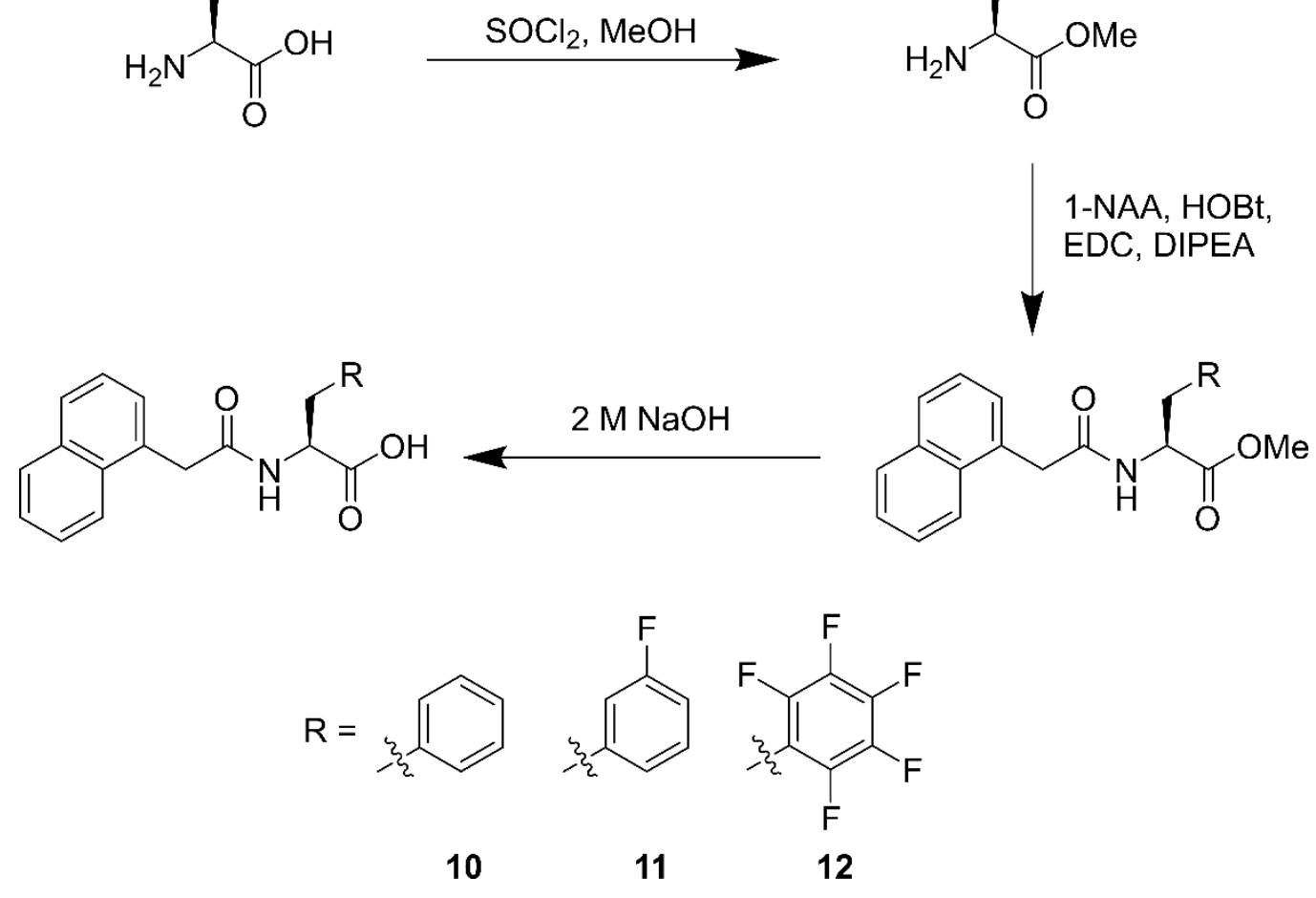

The synthesis of naphthalene protected phenylalanine derivatives 10-12 was performed using the strategy outlined in the Scheme above. Details for the preparation of compound $\mathbf{1 0}$ are provided as a representative example.

L-Phe-OH (250 mg, $1.51 \mathrm{mmol})$ was suspended in methanol $(5 \mathrm{~mL})$ and cooled to $0{ }^{\circ} \mathrm{C}$ while stirring. Thionyl chloride $(132 \mu \mathrm{L}, 1.82 \mathrm{mmol})$ was added dropwise and the solution was warmed to room temperature for one hour. The reaction mixture was then heated to $70^{\circ} \mathrm{C}$ at reflux for three hours. Solvent was removed by rotary evaporation to give a yellow oil. This product was used directly in the next reaction without purification.

1-Naphthaleneacetic acid (1-NAA) (267 mg, $1.44 \mathrm{mmol})$, HOBt (233 mg, $1.72 \mathrm{mmol})$, and 1ethyl-3-(3-dimethylaminopropyl)carbodiimide hydrochloride (EDC $\cdot \mathrm{HCl})(275 \mathrm{mg}, 1.44 \mathrm{mmol})$ were dissolved in $5 \mathrm{~mL}$ of dichloromethane/dimethylformamide (1:1 DCM/DMF). N, Ndipropylethylamine (DIPEA) $(375 \mu \mathrm{L}, 2.15 \mathrm{mmol})$ was added to the solution and stirred for 10 minutes. The product of the previous reaction was dissolved in $5 \mathrm{~mL}$ of $1: 1 \mathrm{DCM} / \mathrm{DMF}$, added to the reaction flask, and the solution was stirred for 24 hours at room temperature. The mixture was concentrated by rotary evaporation to remove DCM, then diluted with $30 \mathrm{~mL}$ of ethyl acetate and washed twice each with $25 \mathrm{~mL}$ of $10 \%$ aqueous citric acid, 5\% aqueous sodium bicarbonate, and brine. The organic layer was dried with anhydrous magnesium sulfate, which was removed by filtration and the resulting solution was dried by rotary evaporation to yield the product. The crude product was purified using column chromatography (silica gel, 3:2 ethyl acetate/hexanes $(v / v)$ ). 
The product (411 mg, $1.18 \mathrm{mmol}$ ) obtained from purification was dissolved in $10 \mathrm{~mL}$ of acetone and treated with $10 \mathrm{~mL}$ of $2 \mathrm{M} \mathrm{NaOH}$ for 3 hours with stirring. The acetone was removed by rotary evaporation and the resulting solution was acidified to $\mathrm{pH} 1-2$ using $1 \mathrm{M} \mathrm{HCl}$. The precipitate was collected by vacuum filtration and dried under vacuum to yield a white powder (396 mg, 1.18 mmol, overall $79 \%$ yield).<smiles>O=C(Cc1cccc2ccccc12)NC(Cc1ccccc1)C(=O)O</smiles>

\section{1-Nap-Phe (10):}

${ }^{1} \mathrm{H}$ NMR (500 MHz, DMSO-d $): \delta 12.79$ (broad s, 1H), $8.52(\mathrm{~d}, \mathrm{~J}=8.0 \mathrm{~Hz}, 1 \mathrm{H}), 7.92(\mathrm{~d}, \mathrm{~J}=8.5$ $\mathrm{Hz}, 1 \mathrm{H}), 7.89(\mathrm{~d}, \mathrm{~J}=8.0 \mathrm{~Hz}, 1 \mathrm{H}), 7.78(\mathrm{~d}, \mathrm{~J}=7.9 \mathrm{~Hz}, 1 \mathrm{H}), 7.49(\mathrm{dd}, \mathrm{J}=7.6 \mathrm{~Hz}, 6.9 \mathrm{~Hz}, 1 \mathrm{H}), 7.43$ (dd, J = 7.7 Hz, 7.5 Hz, 1H), 7.39 (dd, J = 7.8 Hz, 7.4 Hz, 1H), 7.30 (d, J = 6.9 Hz, 1H), 7.27-7.18 (m, 5H), 4.44 (ddd, J = 12.9 Hz, 8.9 Hz, $4.5 \mathrm{~Hz}, 1 \mathrm{H}$ ), 3.89 (s, 2H), 3.08 (dd, J = 14.0 Hz, $4.3 \mathrm{~Hz}$, $1 \mathrm{H}), 2.89(\mathrm{dd}, \mathrm{J}=13.7 \mathrm{~Hz}, 9.9 \mathrm{~Hz}, 1 \mathrm{H}) \mathrm{ppm} ;{ }^{13} \mathrm{C}$ NMR (125 MHz, DMSO-d 6 ): $\delta$ 173.5, 170.5, 138.1, 133.7, 133.0, 132.4, 129.6, 128.7, 128.6, 128.2, 127.4, 126.9, 126.3, 126.0, 125.9, 124.7, 54.0, 37.2 ppm; HRMS (ESI-TOF) (m/z) $334.1433\left(334.1438\right.$ calcd for $\left.\mathrm{C}_{21} \mathrm{H}_{19} \mathrm{NO}_{3}[\mathrm{M}+\mathrm{H}]^{+}\right)$.<smiles>O=C(Cc1cccc2ccccc12)N[C@@H](Cc1cccc(F)c1)C(=O)O</smiles>

\section{1-Nap-3F-Phe (11):}

${ }^{1} \mathrm{H}$ NMR (500 MHz, DMSO-d 6 ): $\delta 12.85$ (broad s, $\left.1 \mathrm{H}\right), 8.57(\mathrm{~d}, \mathrm{~J}=8.0 \mathrm{~Hz}, 1 \mathrm{H}), 7.96-7.85(\mathrm{~m}$, 2H), $7.79(\mathrm{~d}, \mathrm{~J}=8.0 \mathrm{~Hz}, 1 \mathrm{H}), 7.49(\mathrm{dd}, \mathrm{J}=7.5 \mathrm{~Hz}, 7.1 \mathrm{~Hz}, 1 \mathrm{H}), 7.43(\mathrm{dd}, \mathrm{J}=8.0 \mathrm{~Hz}, 7.5 \mathrm{~Hz}, 1 \mathrm{H})$, 7.38 (dd, J = 8.0 Hz, 7.1 Hz, 1H), 7.34-7.25 (m, 2H), 7.13-7.00 (m, 3H), 4.47 (ddd, J = 12.3 Hz, $9.0 \mathrm{~Hz}, 4.1 \mathrm{~Hz}, 1 \mathrm{H}), 3.89$, (s, 2H), $3.12(\mathrm{dd}, \mathrm{J}=13.8 \mathrm{~Hz}, 4.1 \mathrm{~Hz}, 1 \mathrm{H}), 2.91$ (dd, J = 13.6 Hz, 10.6 $\mathrm{Hz}, 1 \mathrm{H}) \mathrm{ppm} ;{ }^{13} \mathrm{C}$ NMR (125 MHz, DMSO-d 6 ): $\delta$ 173.3, 170.5, 162.5 (d, J = $\left.243 \mathrm{~Hz}\right), 141.0(\mathrm{~d}, \mathrm{~J}$ $=7.5 \mathrm{~Hz}), 133.7,132.9,132.4,130.4(\mathrm{~d}, \mathrm{~J}=8.5 \mathrm{~Hz}), 128.7,128.1,127.5,126.0,125.8,124.6$, $116.3(\mathrm{~d}, \mathrm{~J}=21.1 \mathrm{~Hz}), 113.7$ (d, J = 20.7 Hz), 53.7, $36.8 \mathrm{ppm} ;{ }^{19} \mathrm{~F}$ NMR $(376 \mathrm{MHz}$, DMSO-d $): \delta$ -115.10 (dd, $\mathrm{J}=15.7 \mathrm{~Hz}, 9.3 \mathrm{~Hz}) \mathrm{ppm}$; HRMS (ESI-TOF) (m/z) 352.1340 (352.1344 calcd for $\left.\mathrm{C}_{21} \mathrm{H}_{18} \mathrm{FNO}_{3}[\mathrm{M}+\mathrm{H}]^{+}\right)$. 


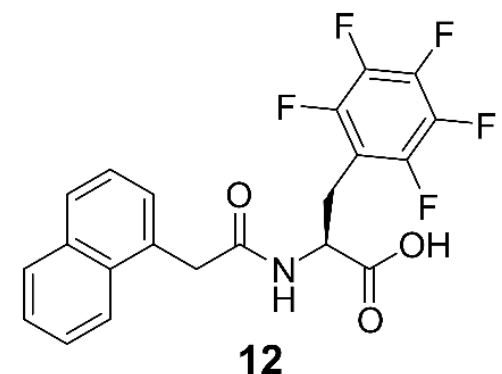

\section{1-Nap-F 5 -Phe (12):}

${ }^{1} \mathrm{H}$ NMR (500 MHz, DMSO-d $)$ ): $\delta 13.10$ (broad s, 1H), $8.58(\mathrm{~d}, \mathrm{~J}=8.0 \mathrm{~Hz}, 1 \mathrm{H}), 7.96(\mathrm{~d}, \mathrm{~J}=8.0$ $\mathrm{Hz}, 1 \mathrm{H}), 7.90(\mathrm{~d}, \mathrm{~J}=8.0 \mathrm{~Hz}, 1 \mathrm{H}), 7.80(\mathrm{~d}, \mathrm{~J}=8.0 \mathrm{~Hz}, 1 \mathrm{H}), 7.49(\mathrm{dd}, \mathrm{J}=7.4 \mathrm{~Hz}, 7.0 \mathrm{~Hz}, 1 \mathrm{H}), 7.45$ $(\mathrm{dd}, \mathrm{J}=7.7 \mathrm{~Hz}, 7.2 \mathrm{~Hz}, 1 \mathrm{H}), 7.40(\mathrm{dd}, \mathrm{J}=7.7 \mathrm{~Hz}, 7.1 \mathrm{~Hz}, 1 \mathrm{H}), 7.34(\mathrm{~d}, \mathrm{~J}=6.8 \mathrm{~Hz}, 1 \mathrm{H}), 4.66-4.53$ (m, 1H), $3.87(\mathrm{~s}, 2 \mathrm{H}), 3.17$ (dd, J = 13.1 Hz, 4.0 Hz, 1H), $3.04(\mathrm{dd}, \mathrm{J}=13.9 \mathrm{~Hz}, 9.1 \mathrm{~Hz}, 1 \mathrm{H}) \mathrm{ppm}$; ${ }^{13} \mathrm{C}$ NMR (125 MHz, DMSO-d 6 ): $\delta$ 172.3, 170.6, 133.7, 132.7, 132.2, 128.7, 128.1, 127.6, 126.1, 126.0, 125.8, 124.6, 50.9, 25.3 ppm; ${ }^{19} \mathrm{~F}$ NMR (376 MHz, DMSO-d 6 ): $\delta-143.57$ (dd, J $=23.6 \mathrm{~Hz}$, $7.1 \mathrm{~Hz}),-158.64$ (t, J = 21.9 Hz), -164.66 (td, J = 22.8 Hz, 6.4 Hz) ppm; HRMS (ESI-TOF) (m/z) 424.0964 (424.0967 calcd for $\mathrm{C}_{21} \mathrm{H}_{14} \mathrm{~F}_{5} \mathrm{NO}_{3}[\mathrm{M}+\mathrm{H}]^{+}$). 


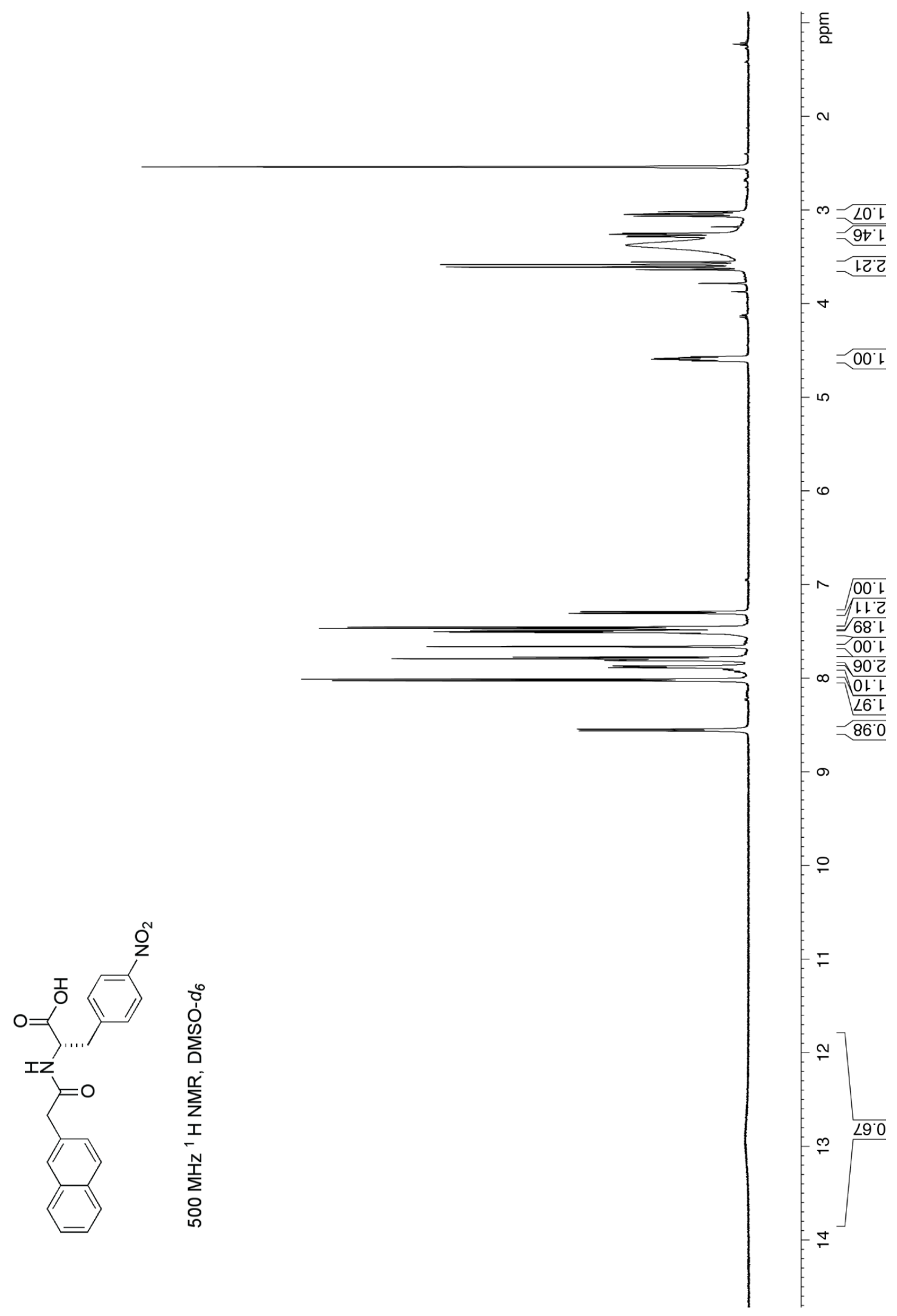

Figure S1. ${ }^{1} \mathrm{H}$ NMR spectrum of 2-Nap-4-NO $2-\mathrm{Phe}(\mathbf{2})$. 


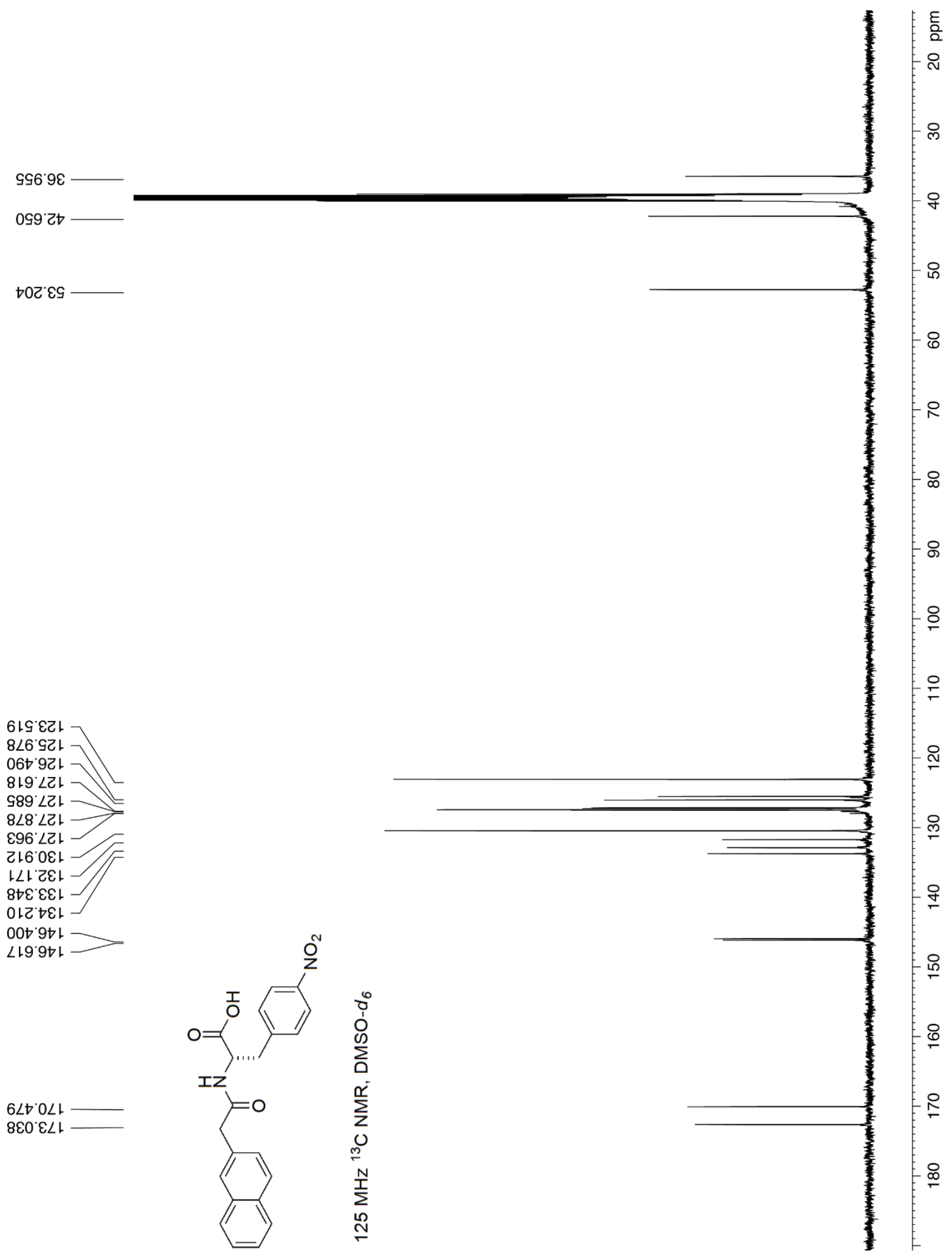

Figure S2. ${ }^{13} \mathrm{C}$ NMR spectrum of 2-Nap-4-NO $-\mathrm{Phe}(2)$. 


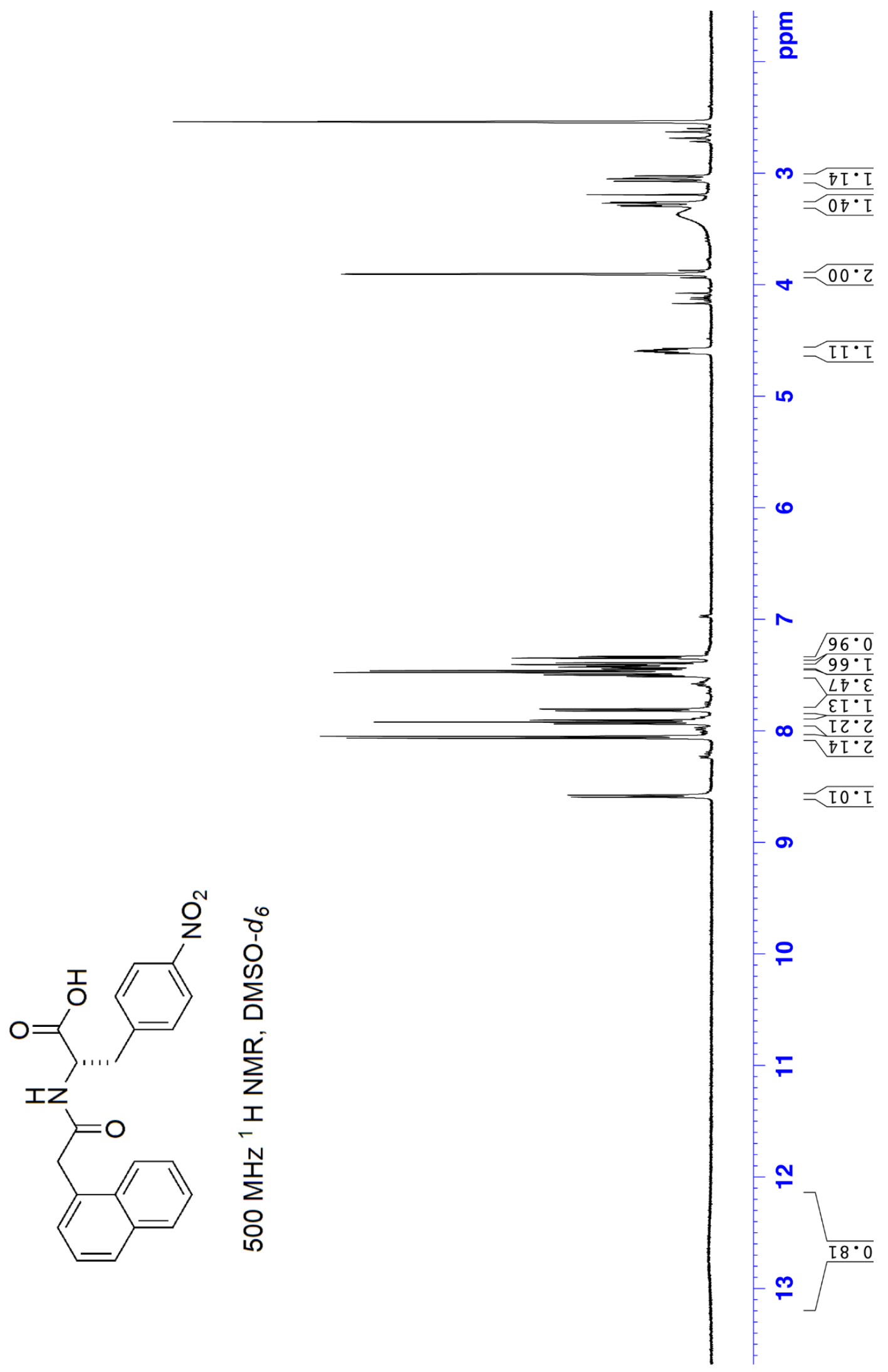

Figure S3. ${ }^{1} \mathrm{H}$ NMR spectrum of 1-Nap-4-NO2-Phe (3). 


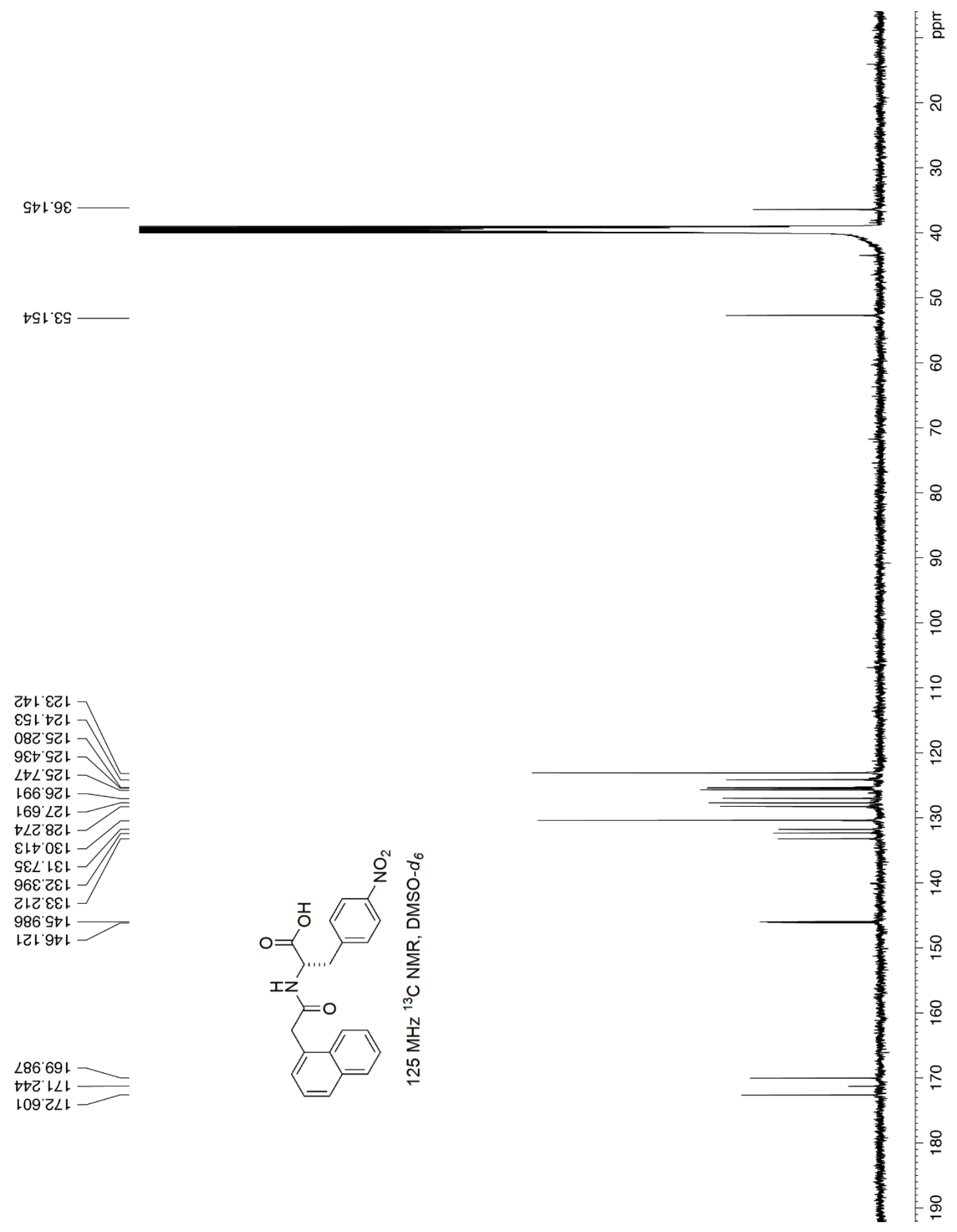

Figure S4. ${ }^{13} \mathrm{C}$ NMR spectrum of 1-Nap-4-NO $-\mathrm{Phe}(3)$. 


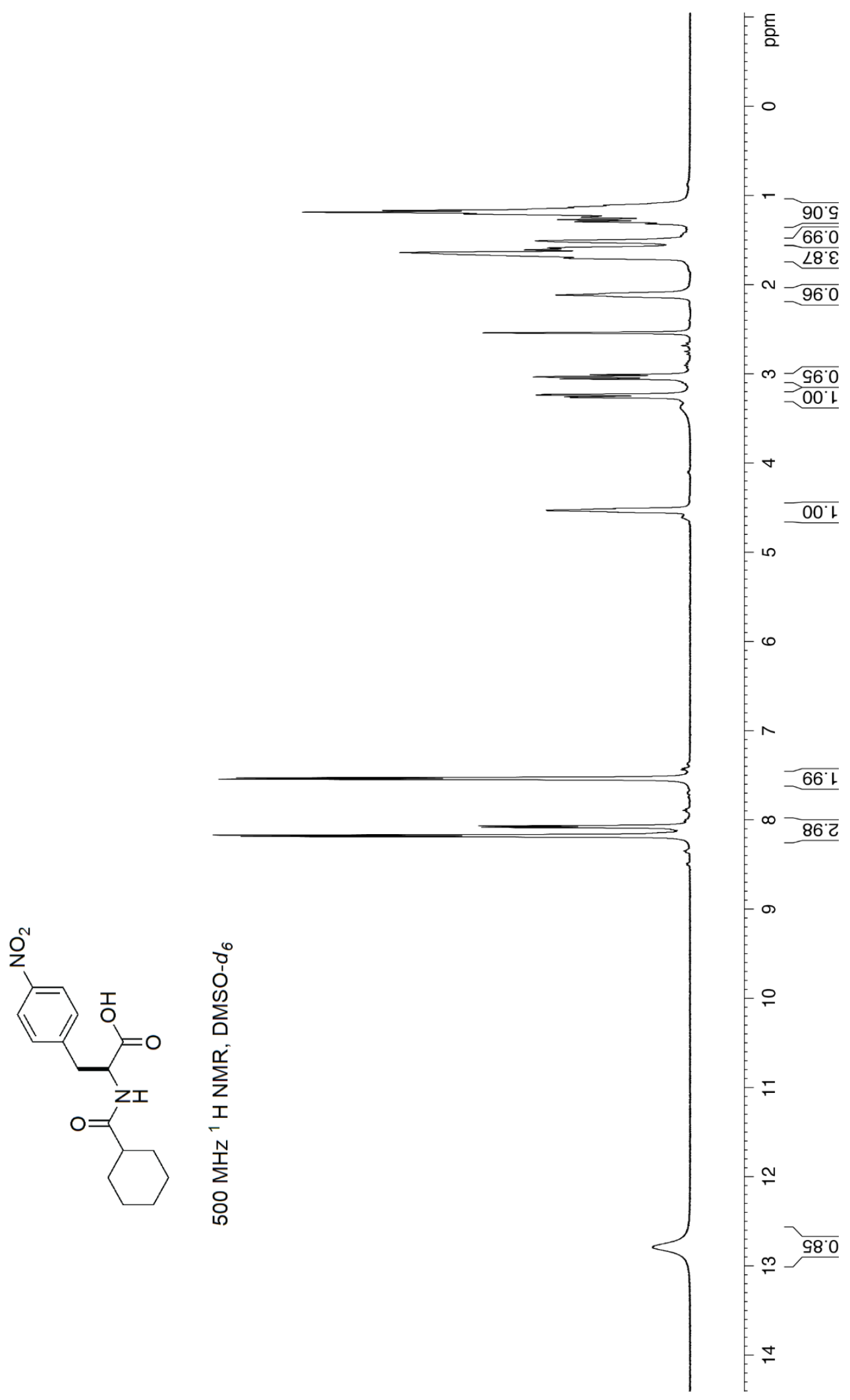

Figure S5. ${ }^{1} \mathrm{H}$ NMR spectrum of $\mathrm{Cy}-4-\mathrm{NO}_{2}-\mathrm{Phe}(4)$. 


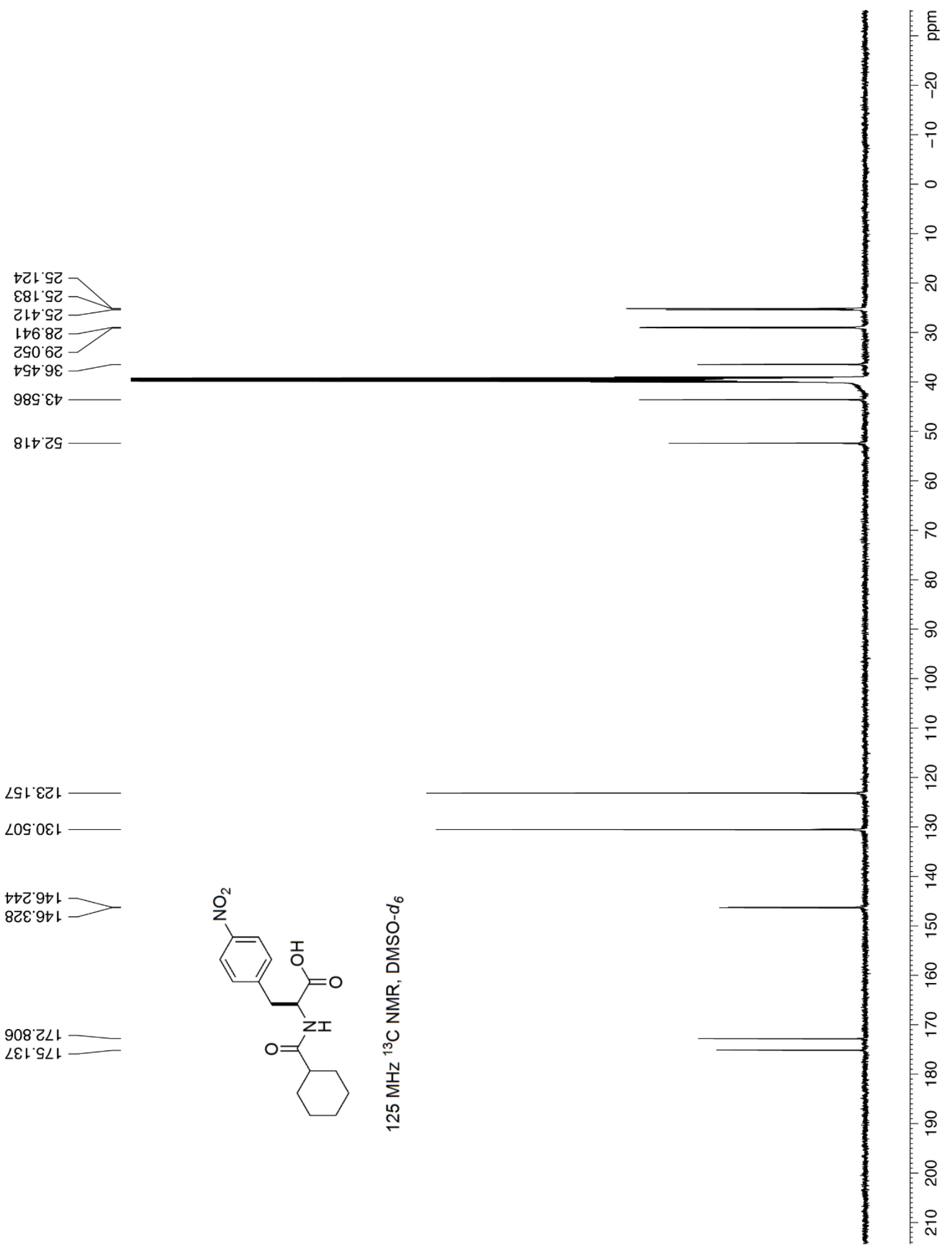

Figure S6. ${ }^{13} \mathrm{C}$ NMR spectrum of $\mathrm{Cy}-4-\mathrm{NO}_{2}-\mathrm{Phe}(4)$. 


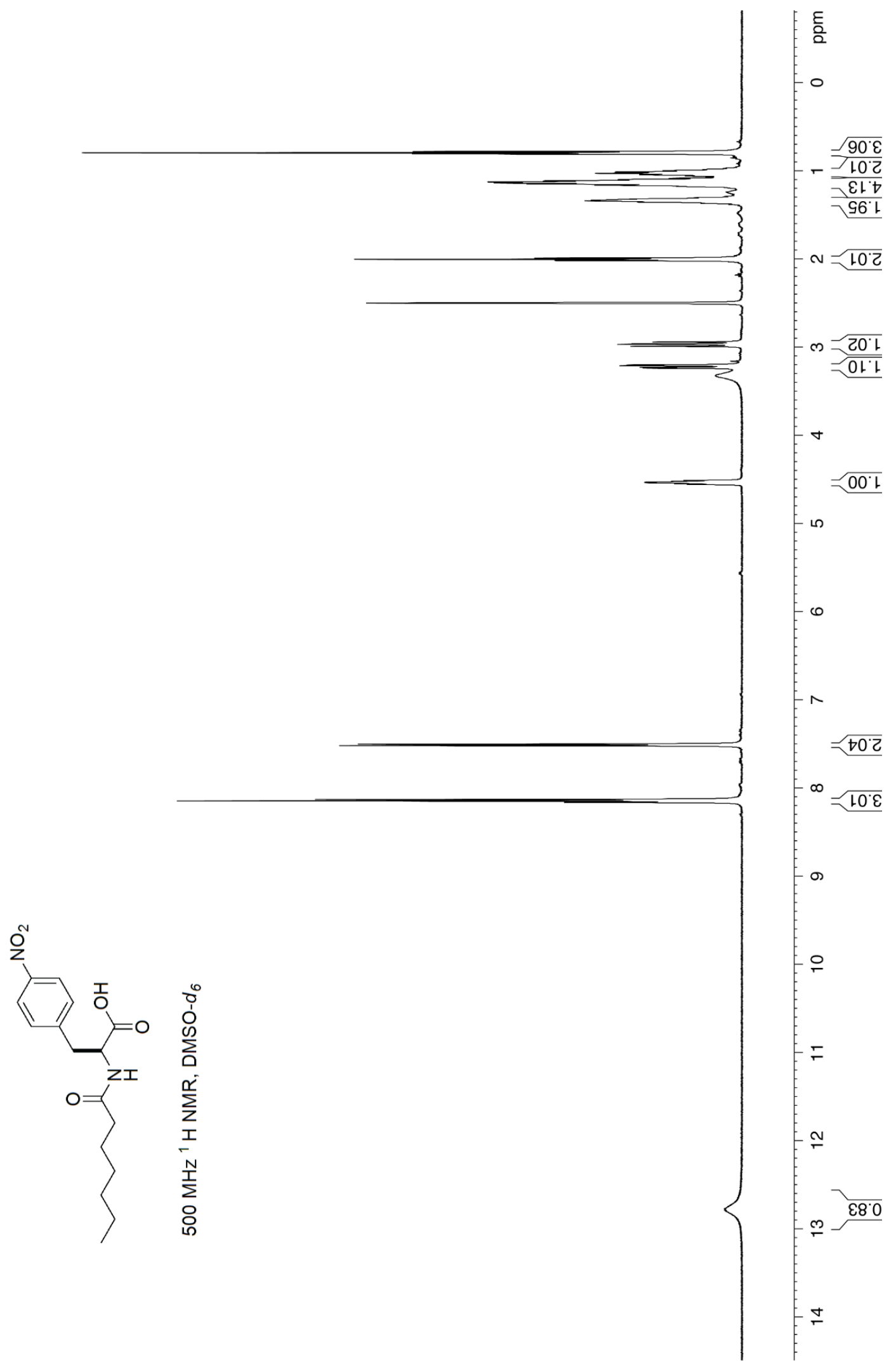

Figure S7. ${ }^{1} \mathrm{H}$ NMR spectrum of $\mathrm{Hex}-4-\mathrm{NO}_{2}-\mathrm{Phe}(\mathbf{5})$. 


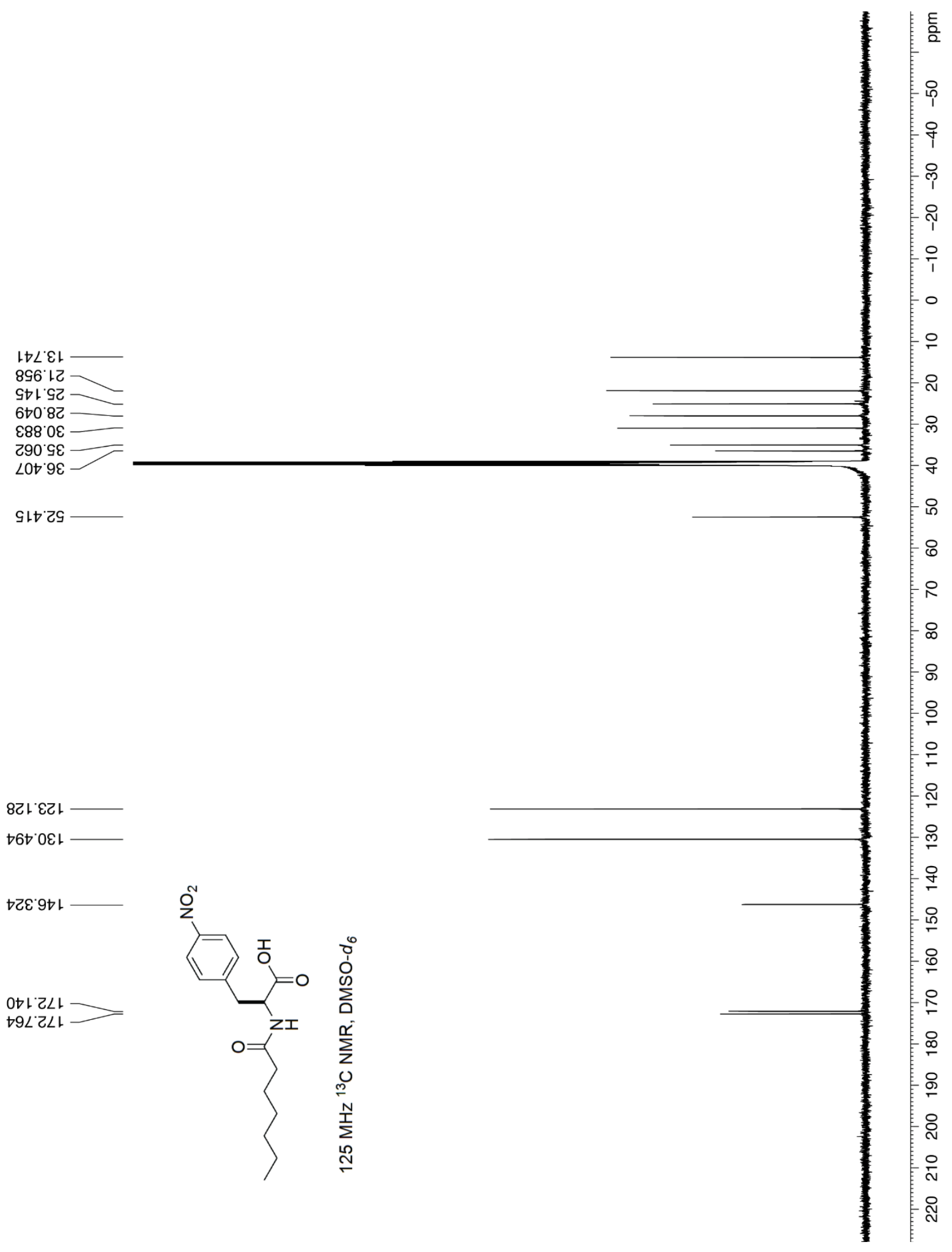

Figure S8. ${ }^{13} \mathrm{C}$ NMR spectrum of $\mathrm{Hex}-4-\mathrm{NO}_{2}-\mathrm{Phe}(\mathbf{5})$. 


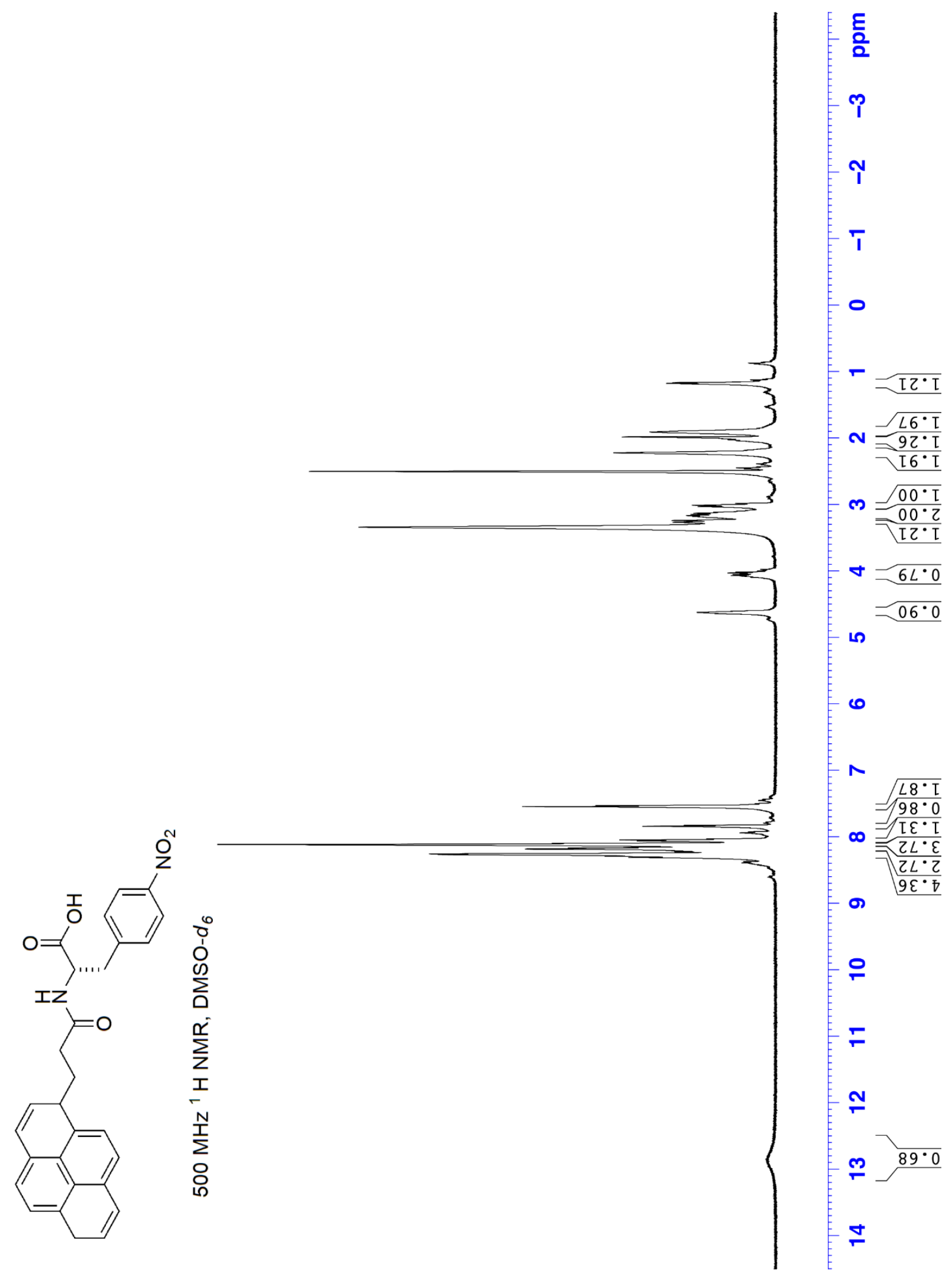

Figure S9. ${ }^{1} \mathrm{H}$ NMR spectrum of Pyr-4-NO $-\mathrm{Phe}(6)$. 


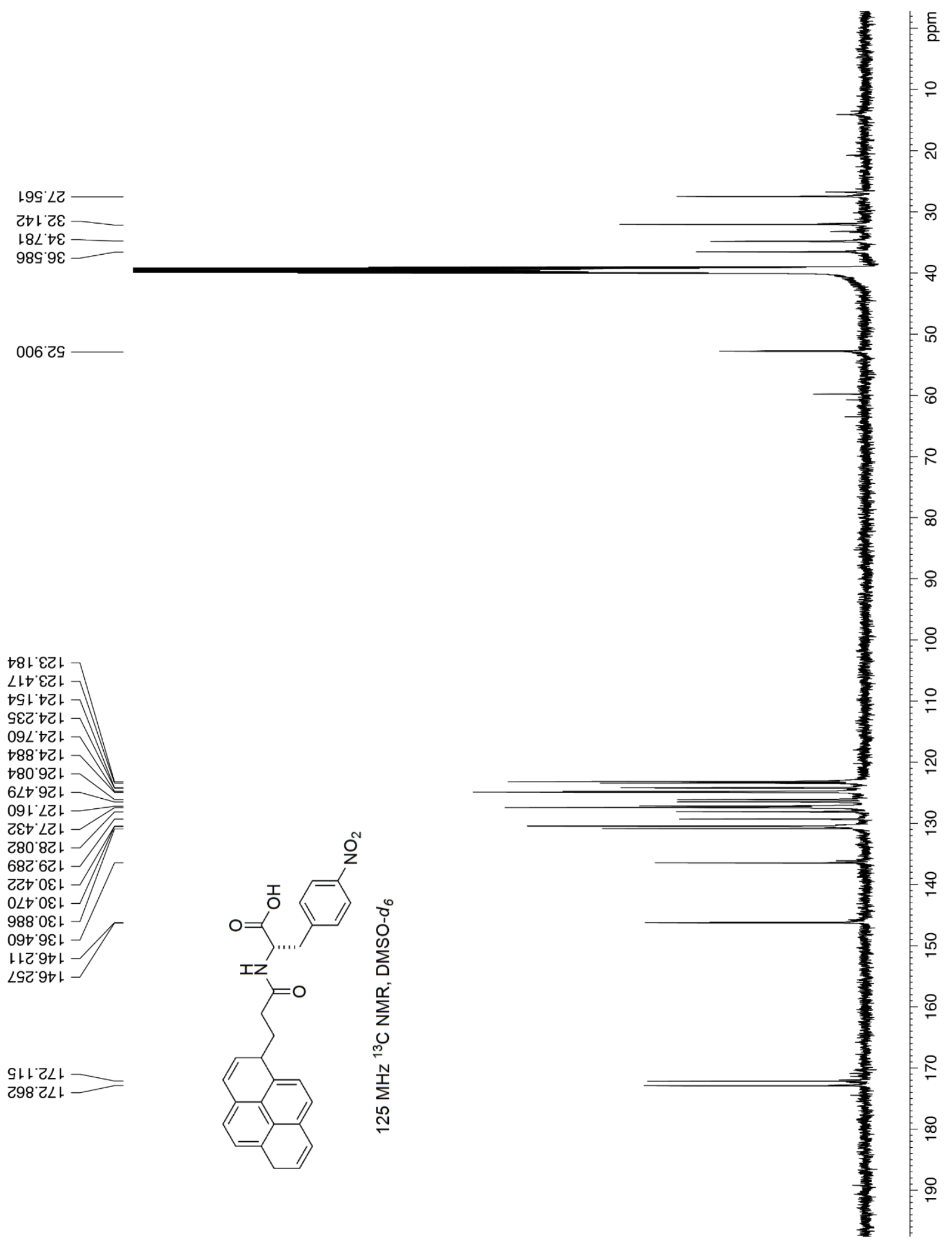

Figure S10. ${ }^{13} \mathrm{C}$ NMR spectrum of Pyr-4-NO $-\mathrm{Nhe}(6)$. 


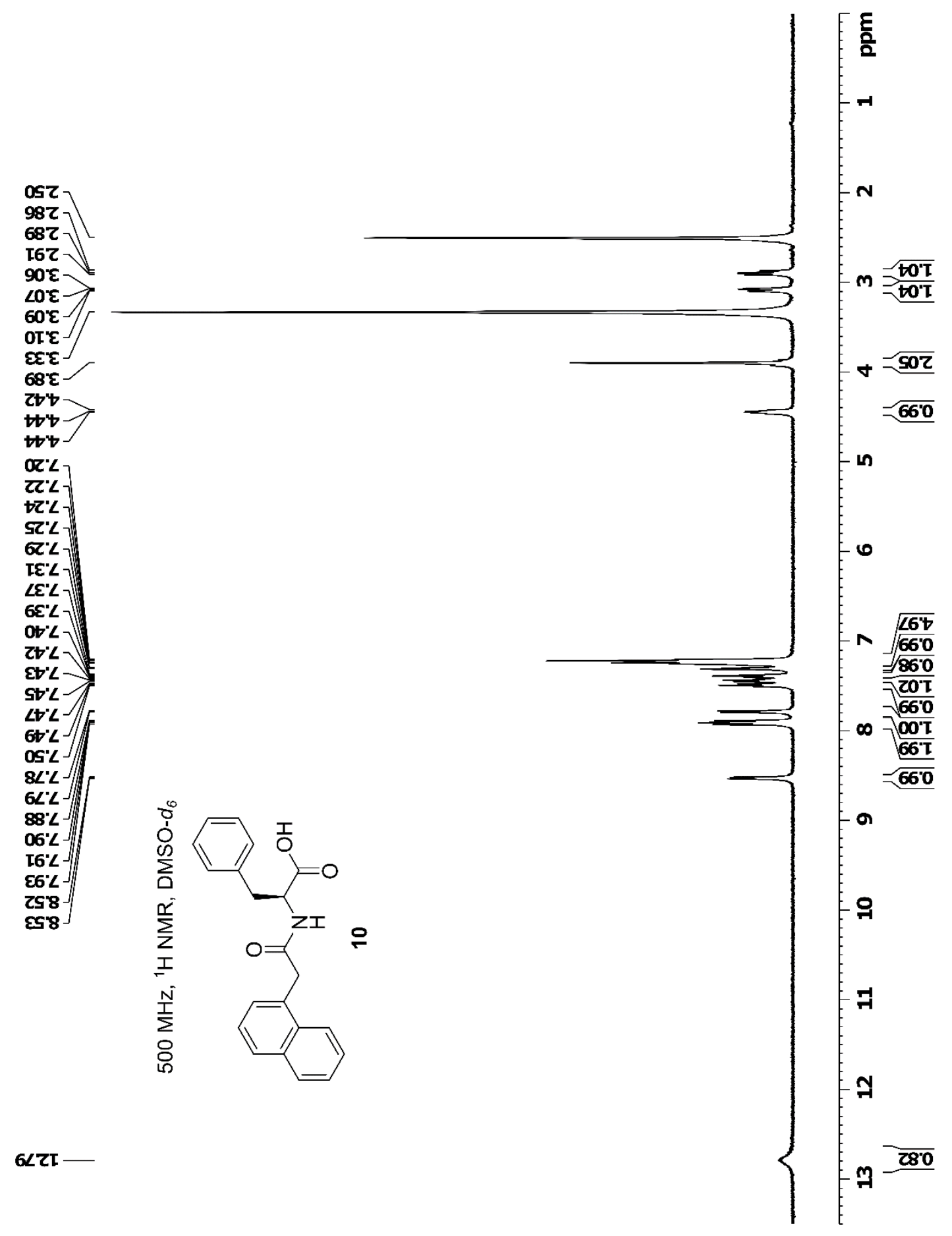

Figure S11. ${ }^{1} \mathrm{H}$ NMR spectrum of 1-Nap-Phe (10). 


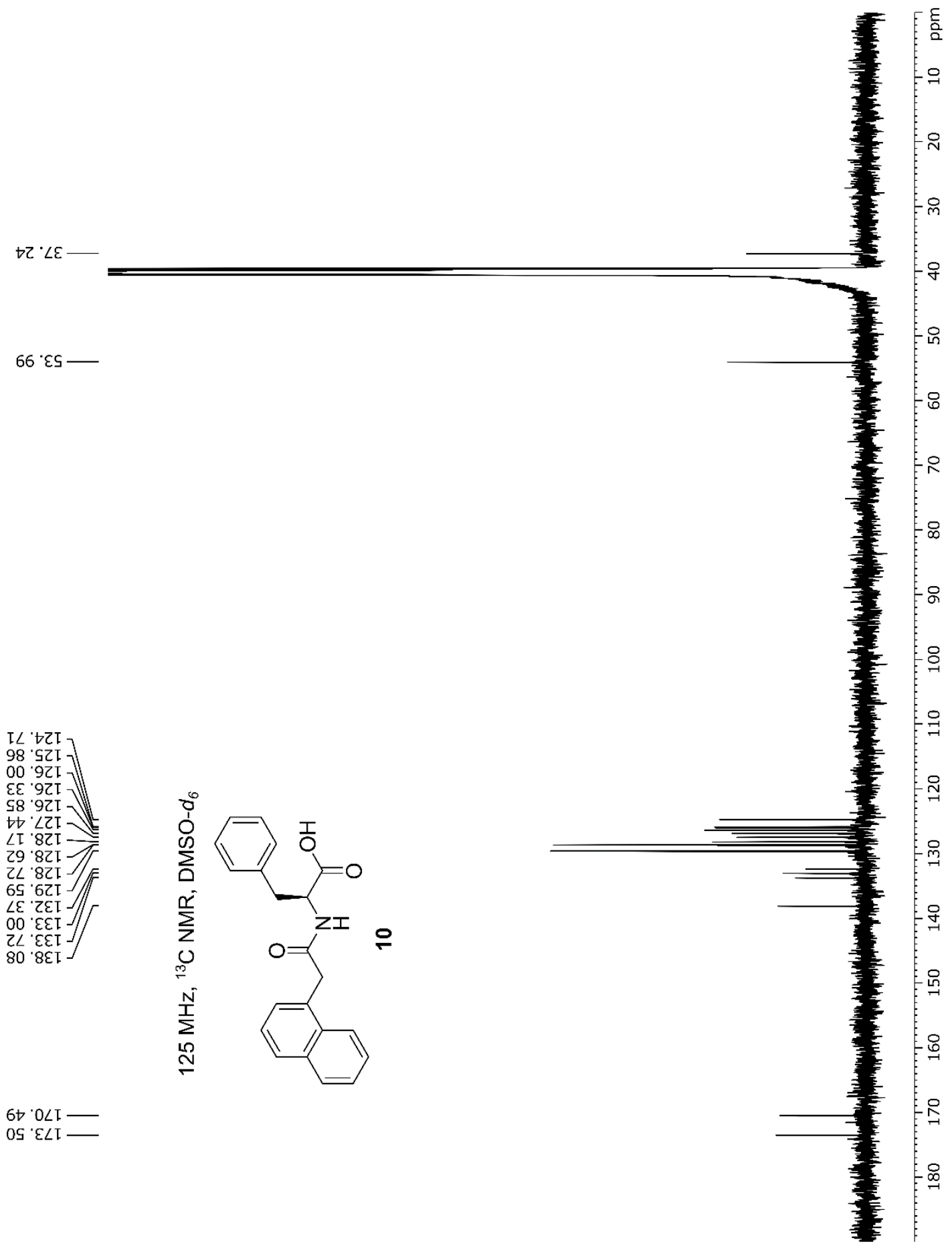

Figure S12. ${ }^{13} \mathrm{C}$ NMR spectrum of 1-Nap-Phe (10). 


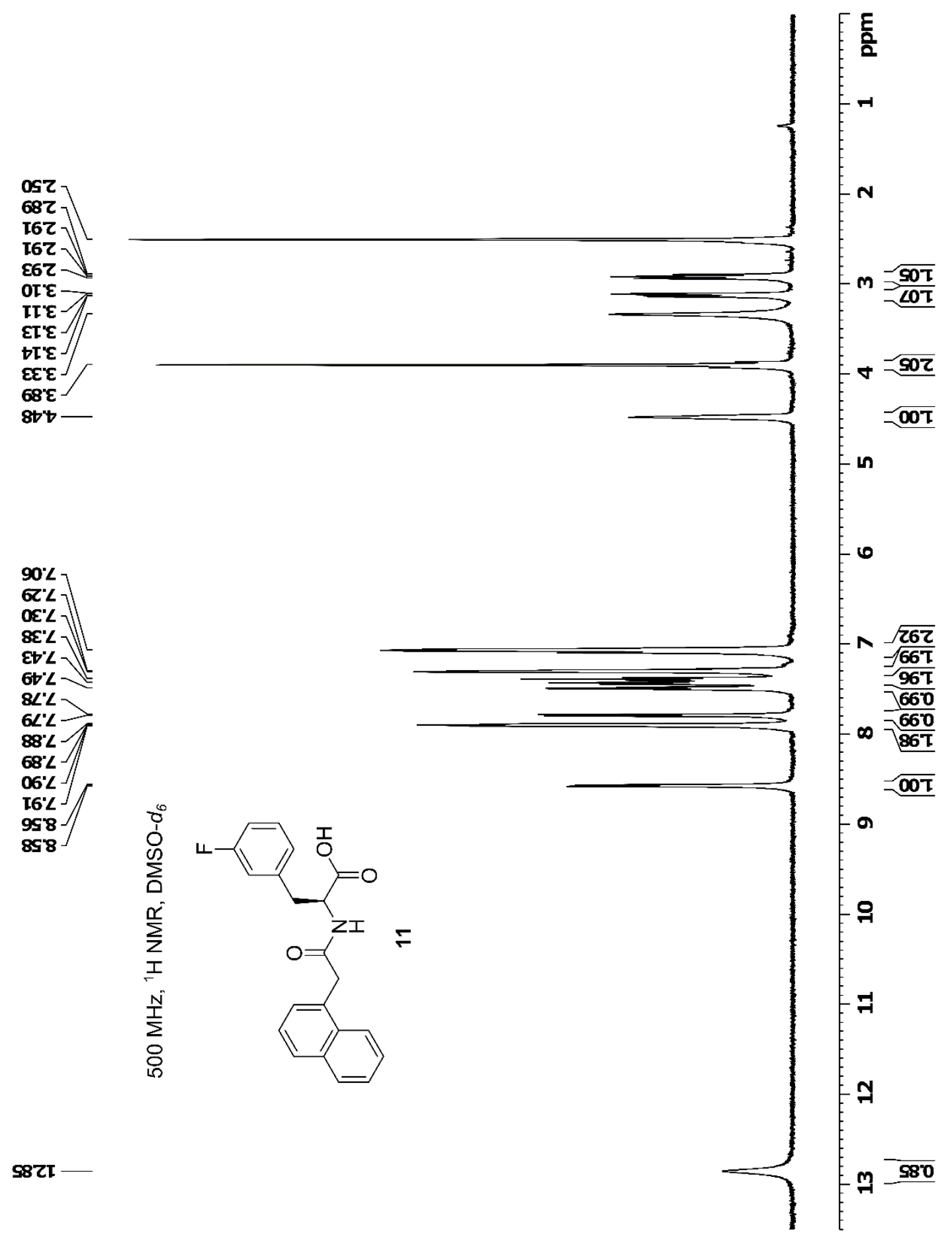

Figure S13. ${ }^{1} \mathrm{H}$ NMR spectrum of 1-Nap-3F-Phe (11). 


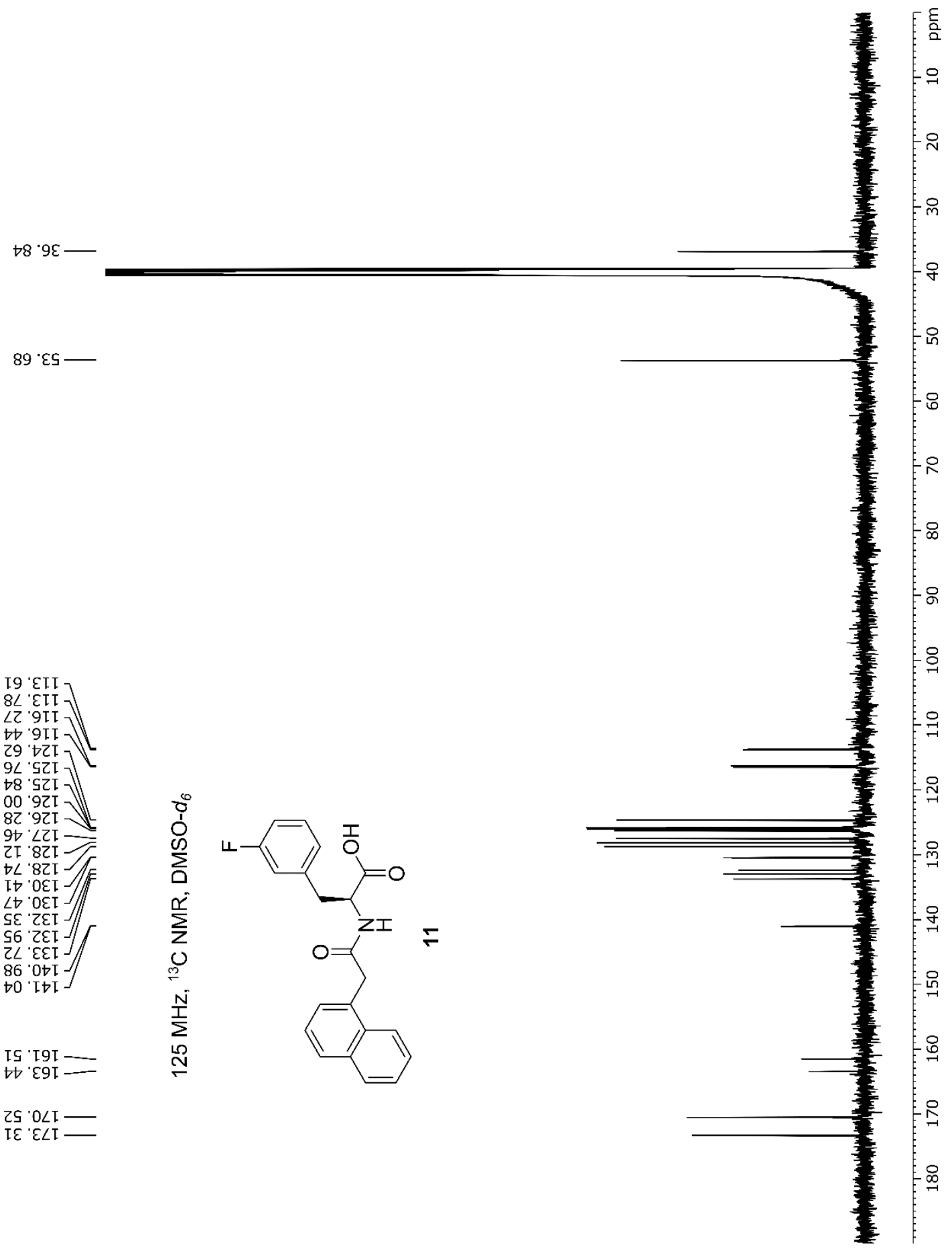

Figure S14. ${ }^{13} \mathrm{C}$ NMR spectrum of 1-Nap-3F-Phe (11). 


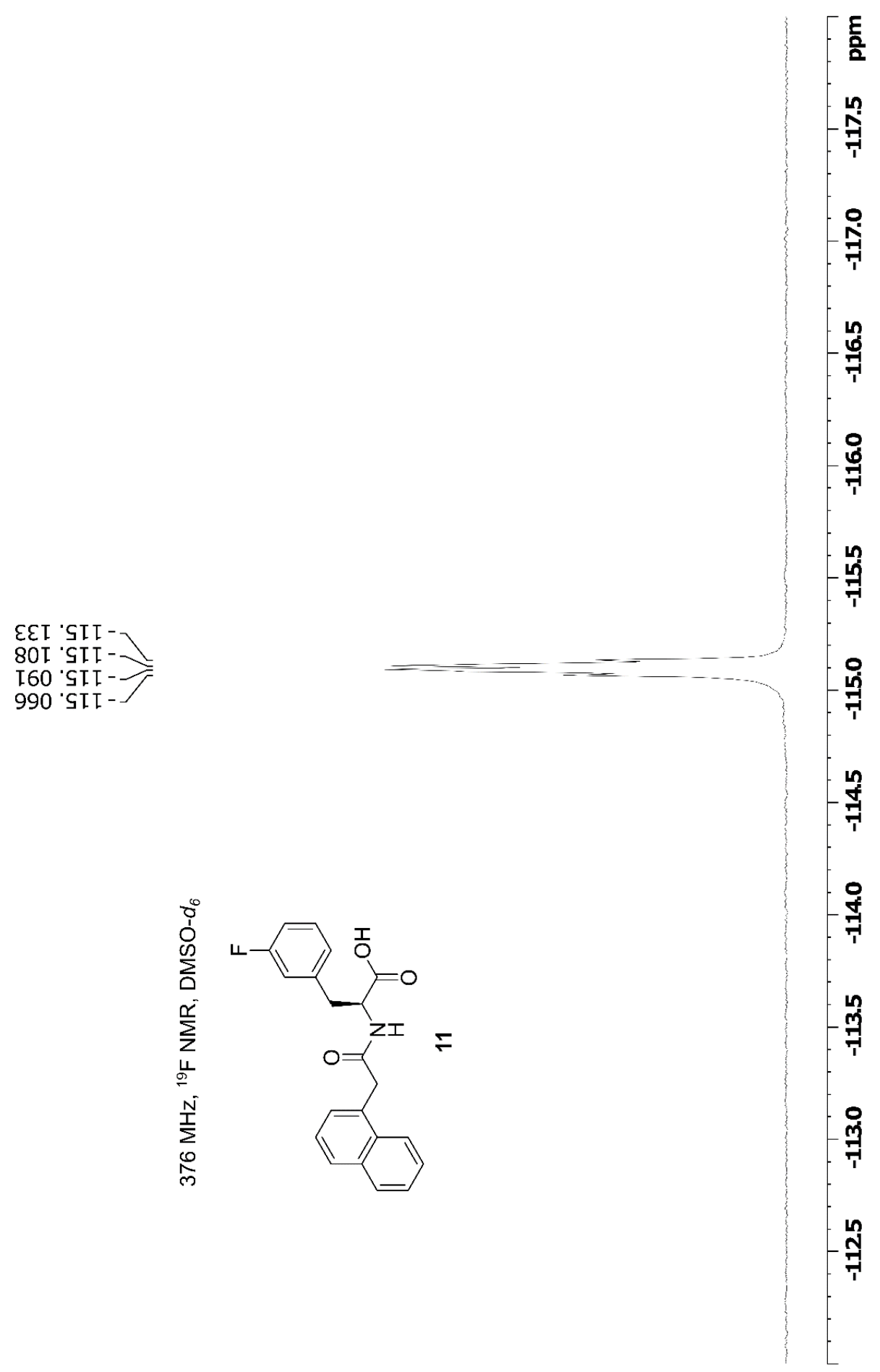

Figure S15. ${ }^{19} \mathrm{~F}$ NMR spectrum of 1-Nap-3F-Phe (11). 


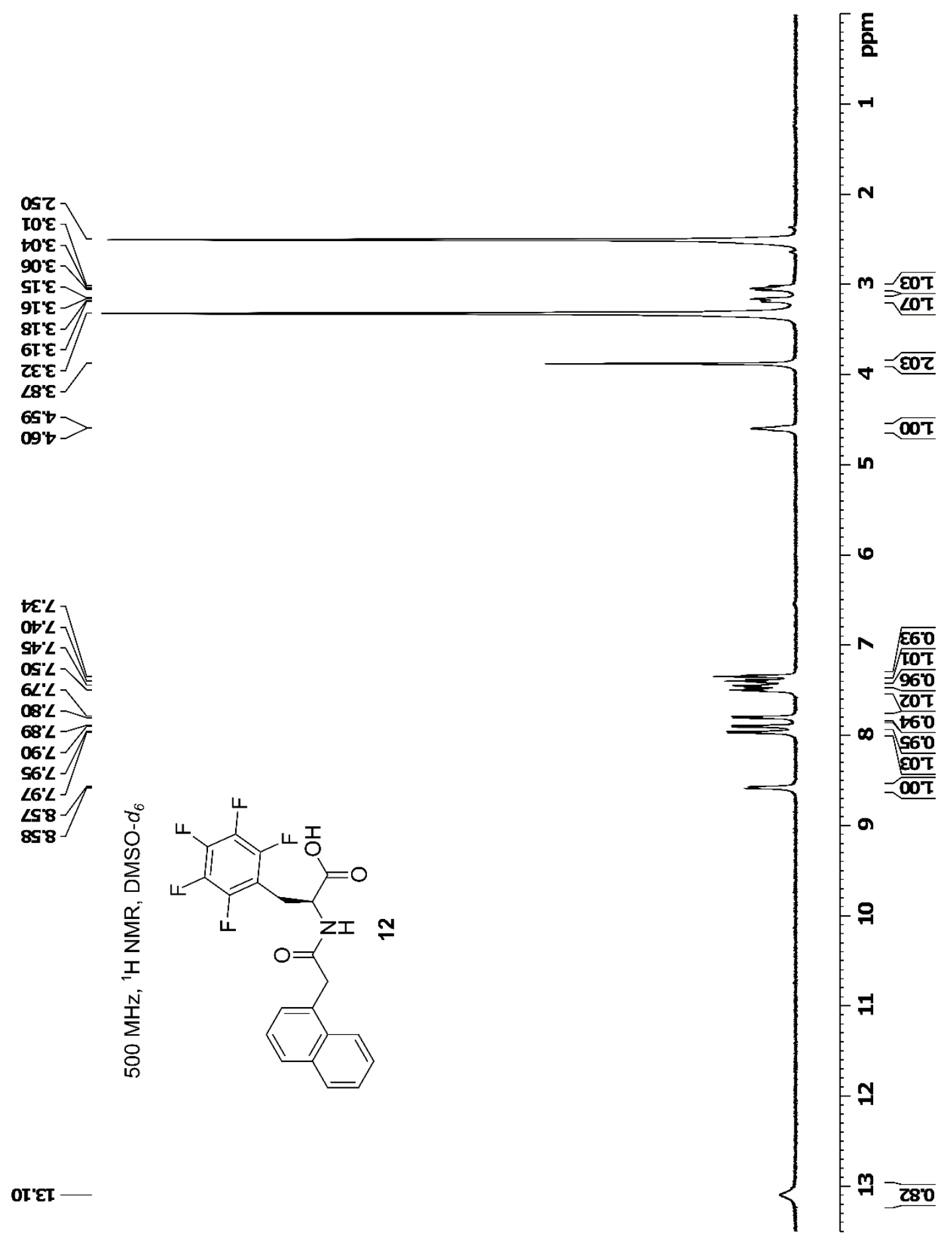

Figure S16. ${ }^{1} \mathrm{H}$ NMR spectrum of 1-Nap-F 5 -Phe (12). 


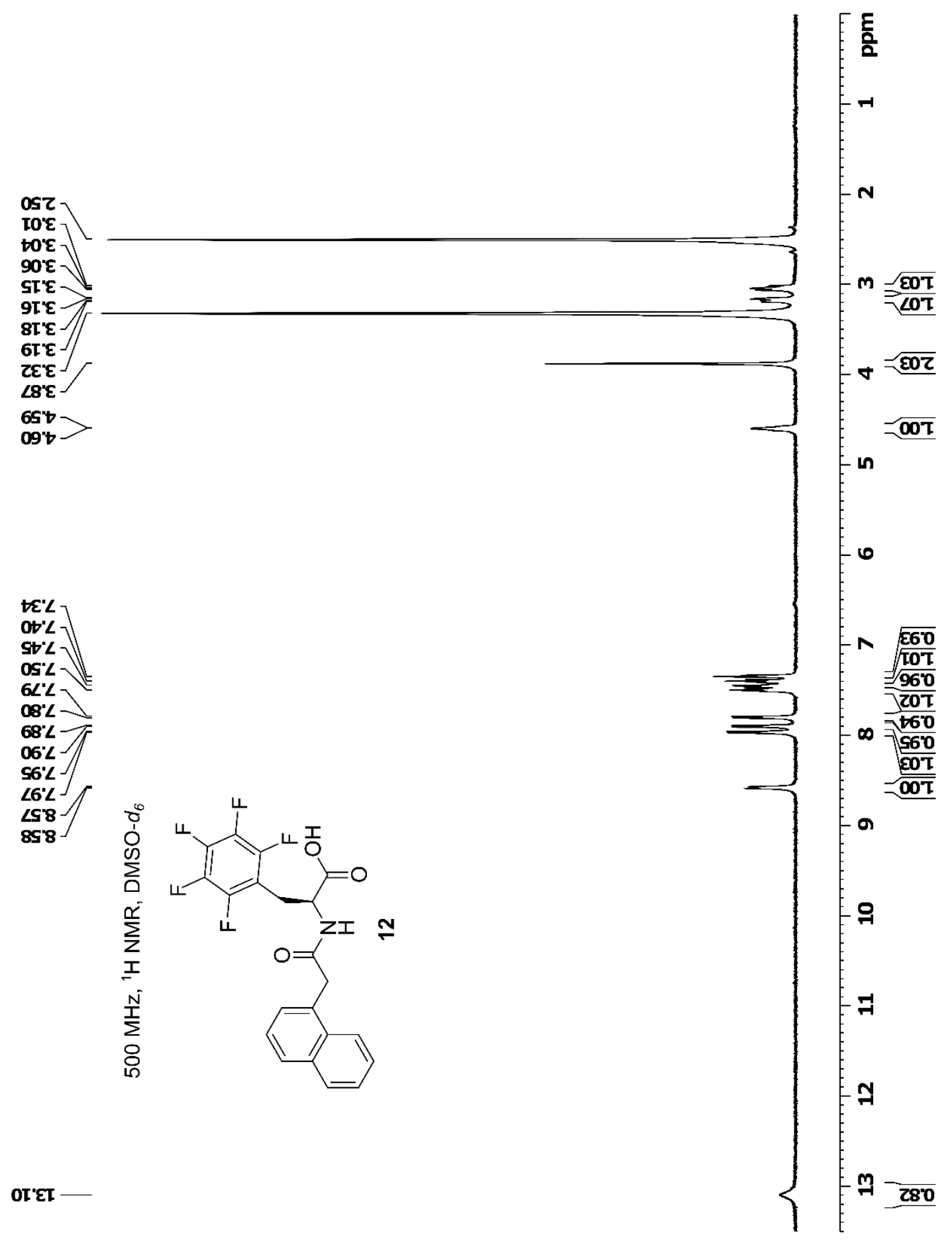

Figure S17. ${ }^{13} \mathrm{C}$ NMR spectrum of $1-\mathrm{Nap}-\mathrm{F}_{5}-\mathrm{Phe}(\mathbf{1 2})$. 

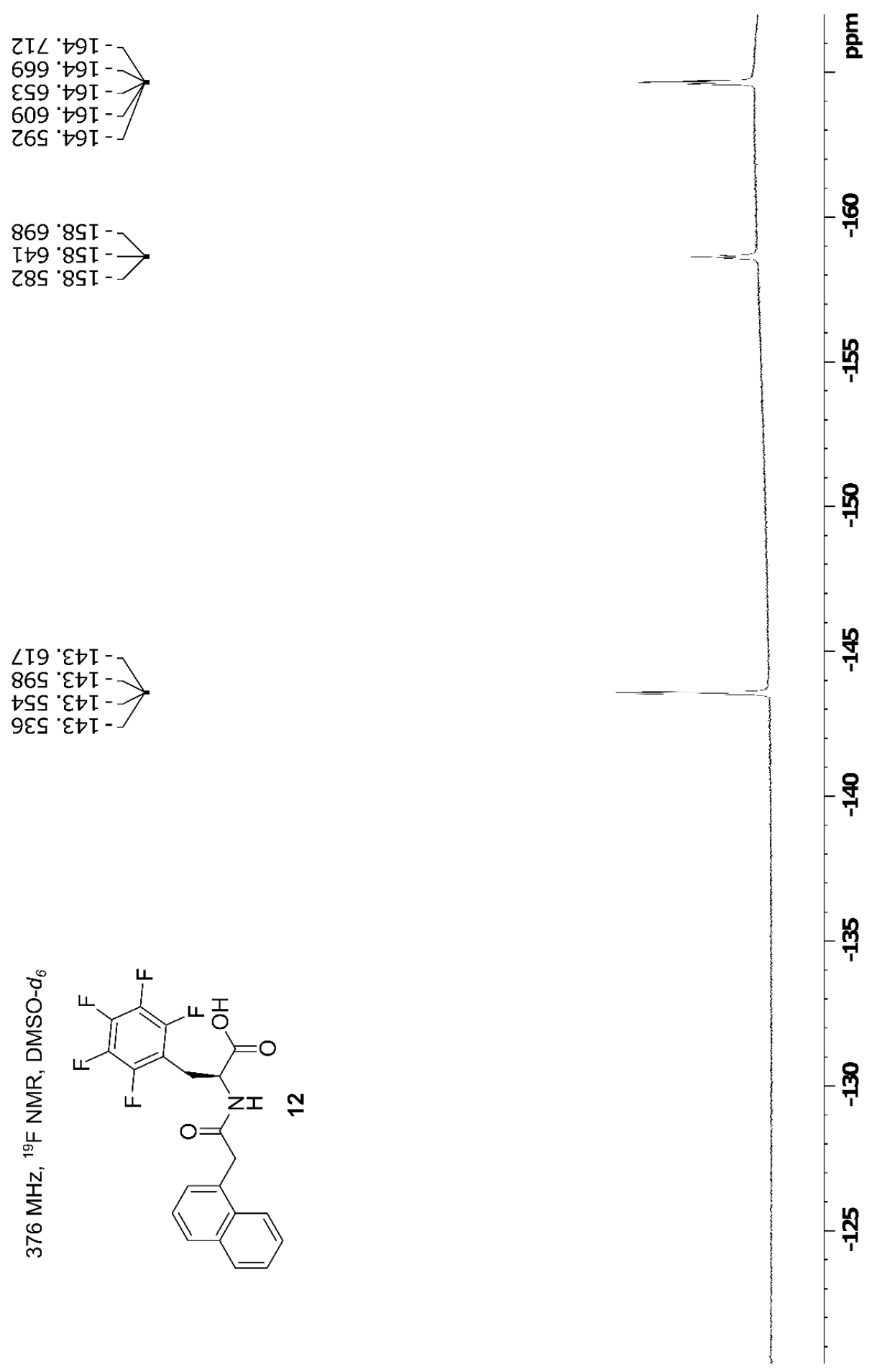

Figure S18. ${ }^{19} \mathrm{~F}$ NMR spectrum of $1-\mathrm{Nap}-\mathrm{F}_{5}-\mathrm{Phe}(\mathbf{1 2})$. 


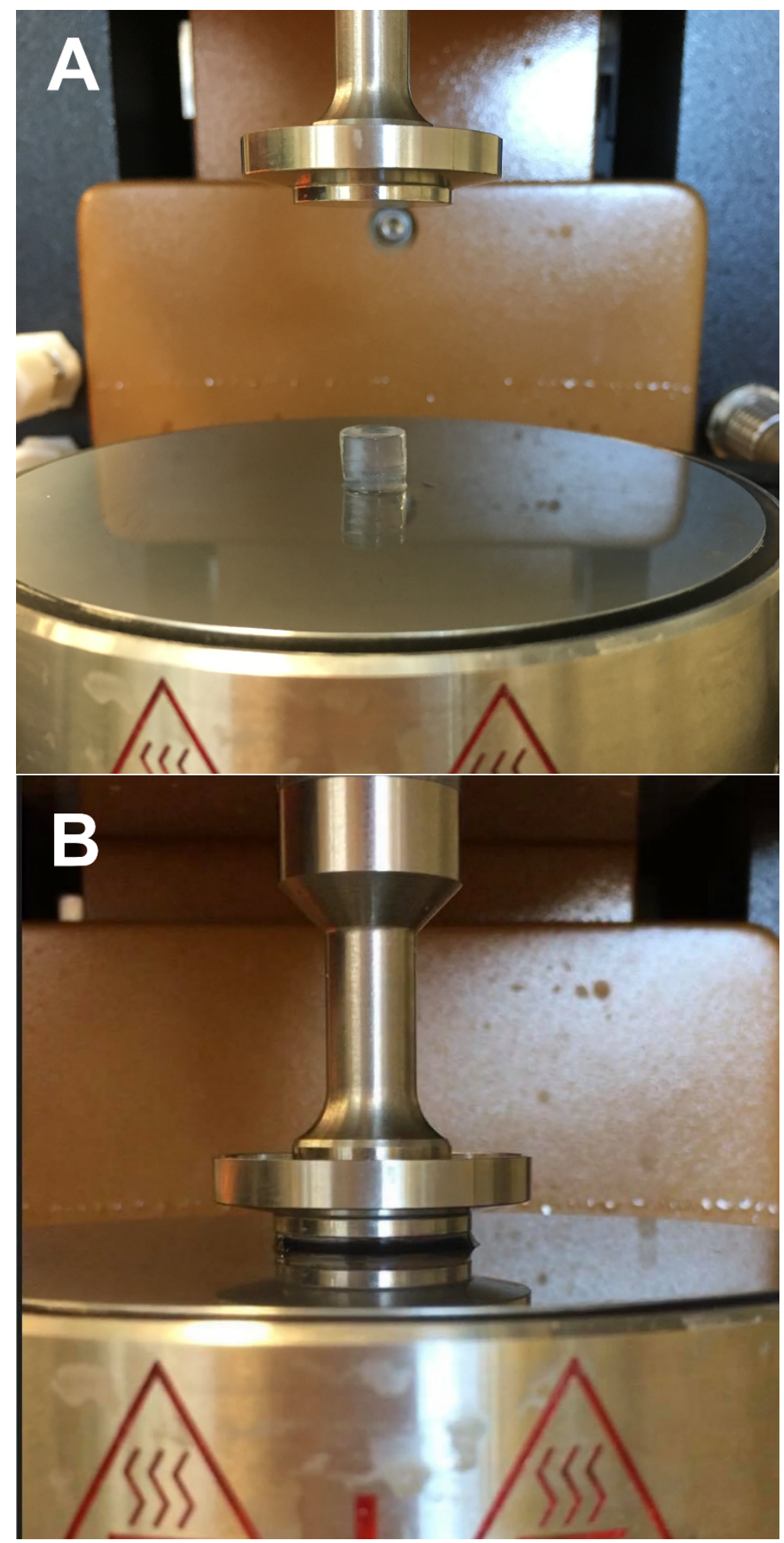

Figure S19. Digital image of oscillatory rheology setup. (A) An approximately $0.5 \mathrm{~mL}$ cylindrical portion of a hydrogel of $1-\mathrm{Nap}-\mathrm{F}_{5}-\mathrm{Phe}(\mathbf{1 2})$ was cut in a $1.5 \mathrm{~mL}$ plastic microcentrifuge tube and transferred to the rheometer stage. (B) The parallel plate geometry was lowered until the hydrogel contacted the entire geometry surface. 

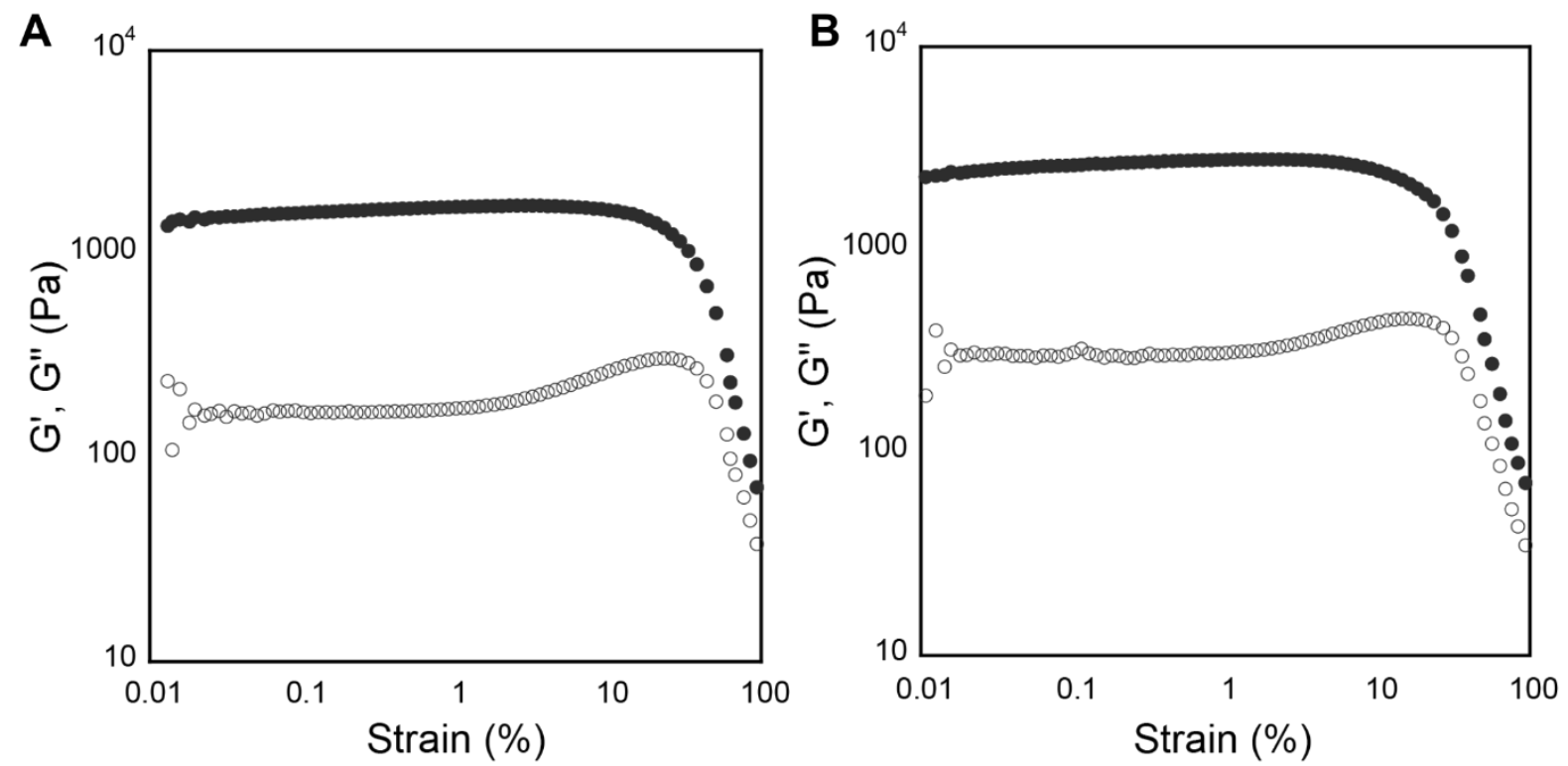

Figure S20. Strain sweep data collected via oscillatory rheology for $7.5 \mathrm{mM}$ hydrogels of compounds 8-9 made via the GdL pH switch method. $\mathrm{G}^{\prime}$ and $\mathrm{G}^{\prime \prime}$ values $(\mathrm{Pa})$ are represented by closed circles and open circles, respectively. (A) Compound 8. (B) Compound 9.
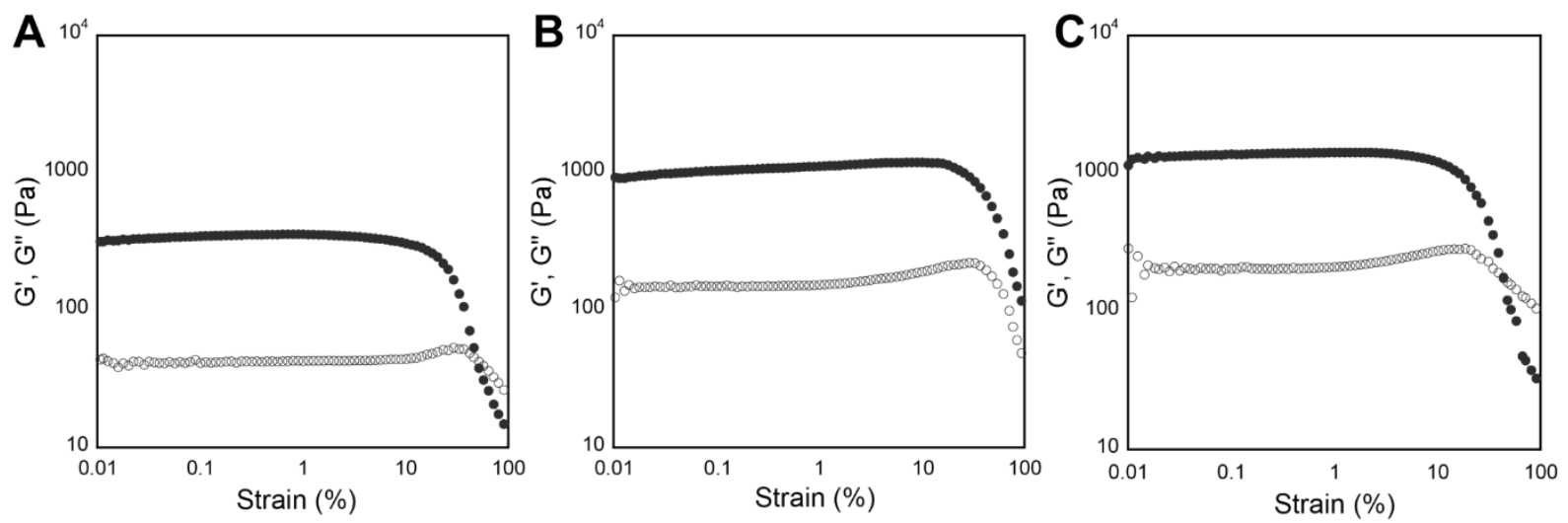

Figure S21. Strain sweep data collected via oscillatory rheology for $7.5 \mathrm{mM}$ hydrogels of compounds 10-12 made via the GdL pH switch method. $\mathrm{G}^{\prime}$ and $\mathrm{G}^{\prime \prime}$ values $(\mathrm{Pa})$ are represented by closed circles and open circles, respectively. (A) Compound 10. (B) Compound 11. (C) Compound 12. 

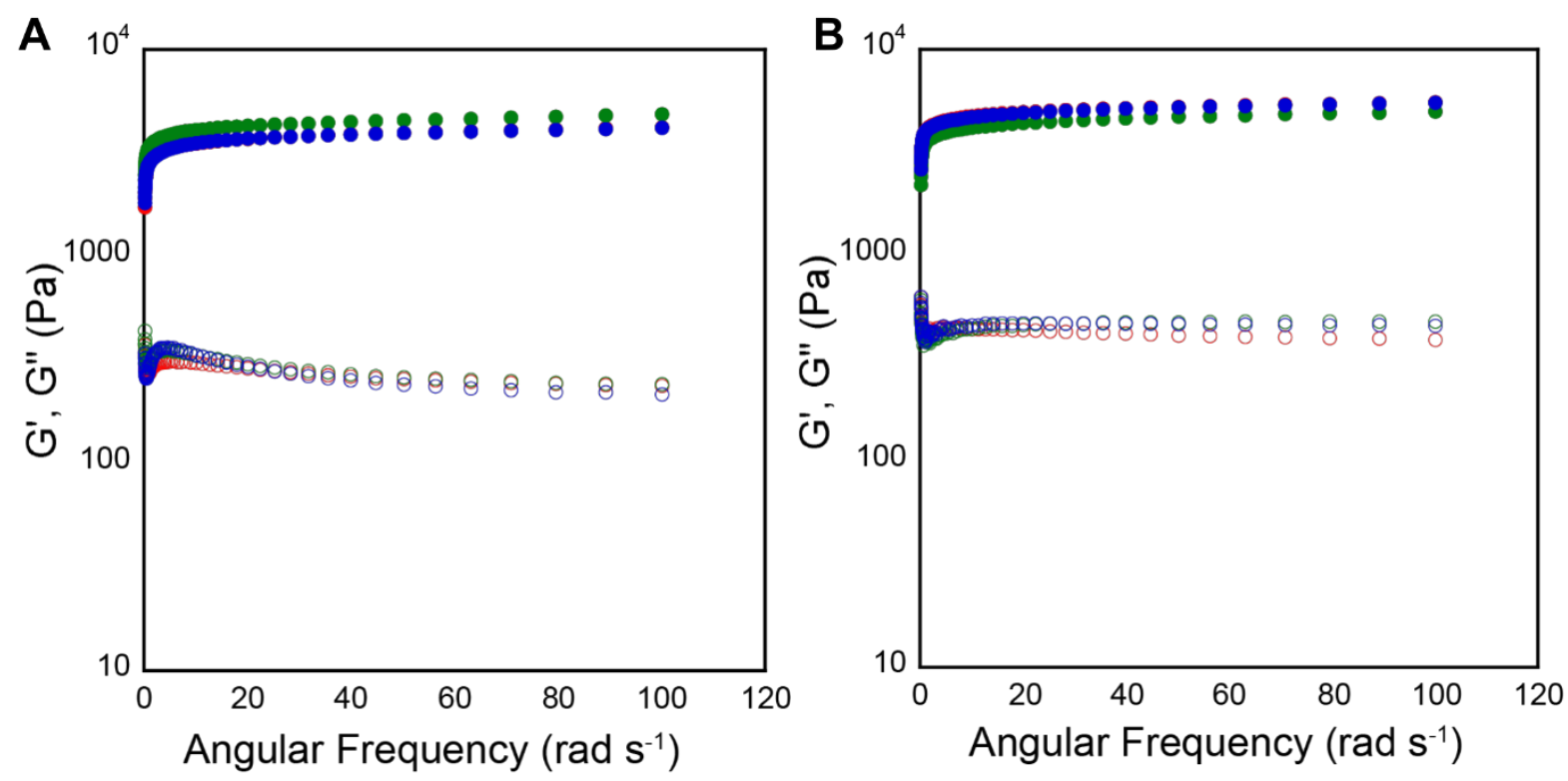

Figure S22. Frequency sweep data collected via oscillatory rheology for $7.5 \mathrm{mM}$ hydrogels of compounds 8-9 made via the GdL pH switch method. $\mathrm{G}^{\prime}$ and $\mathrm{G}^{\prime \prime}$ values $(\mathrm{Pa})$ are represented by closed circles and open circles, respectively. Each plot contains three distinct measurements of three separate hydrogels. (A) Compound 8. (B) Compound 9.
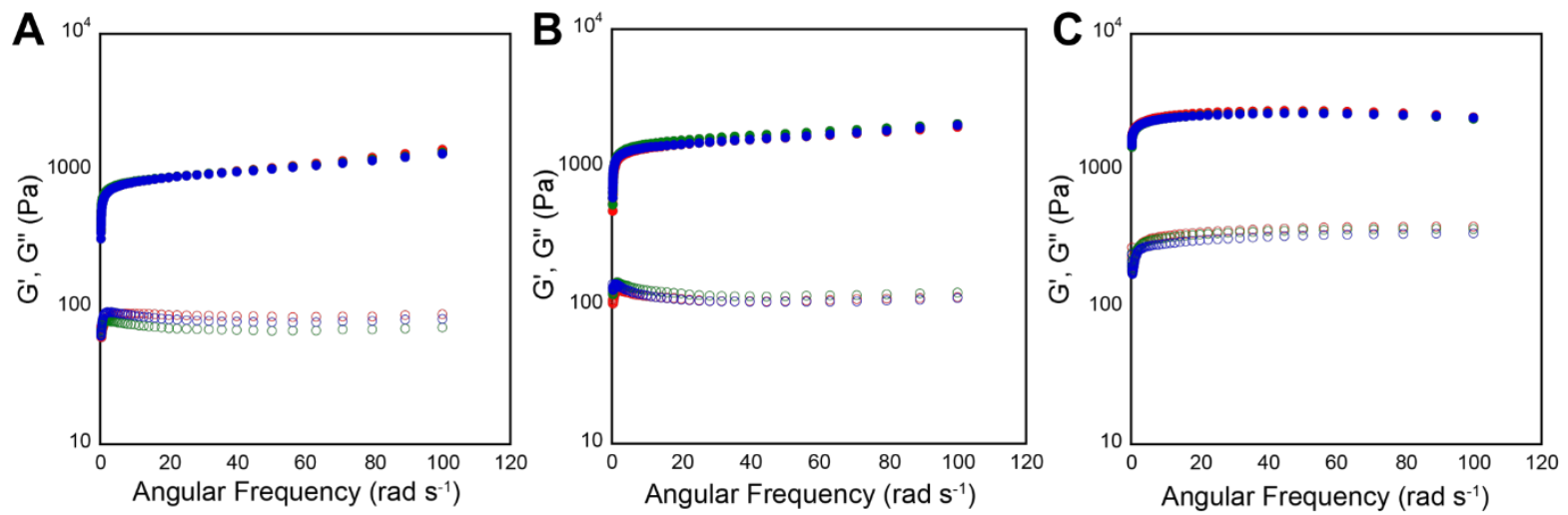

Figure S23. Frequency sweep data collected via oscillatory rheology for $7.5 \mathrm{mM}$ hydrogels of compounds 10-12 made via the GdL pH switch method. $\mathrm{G}^{\prime}$ and $\mathrm{G}^{\prime \prime}$ values $(\mathrm{Pa})$ are represented by closed circles and open circles, respectively. Each plot contains three distinct measurements of three separate hydrogels. (A) Compound 10. (B) Compound 11. (C) Compound 12. 

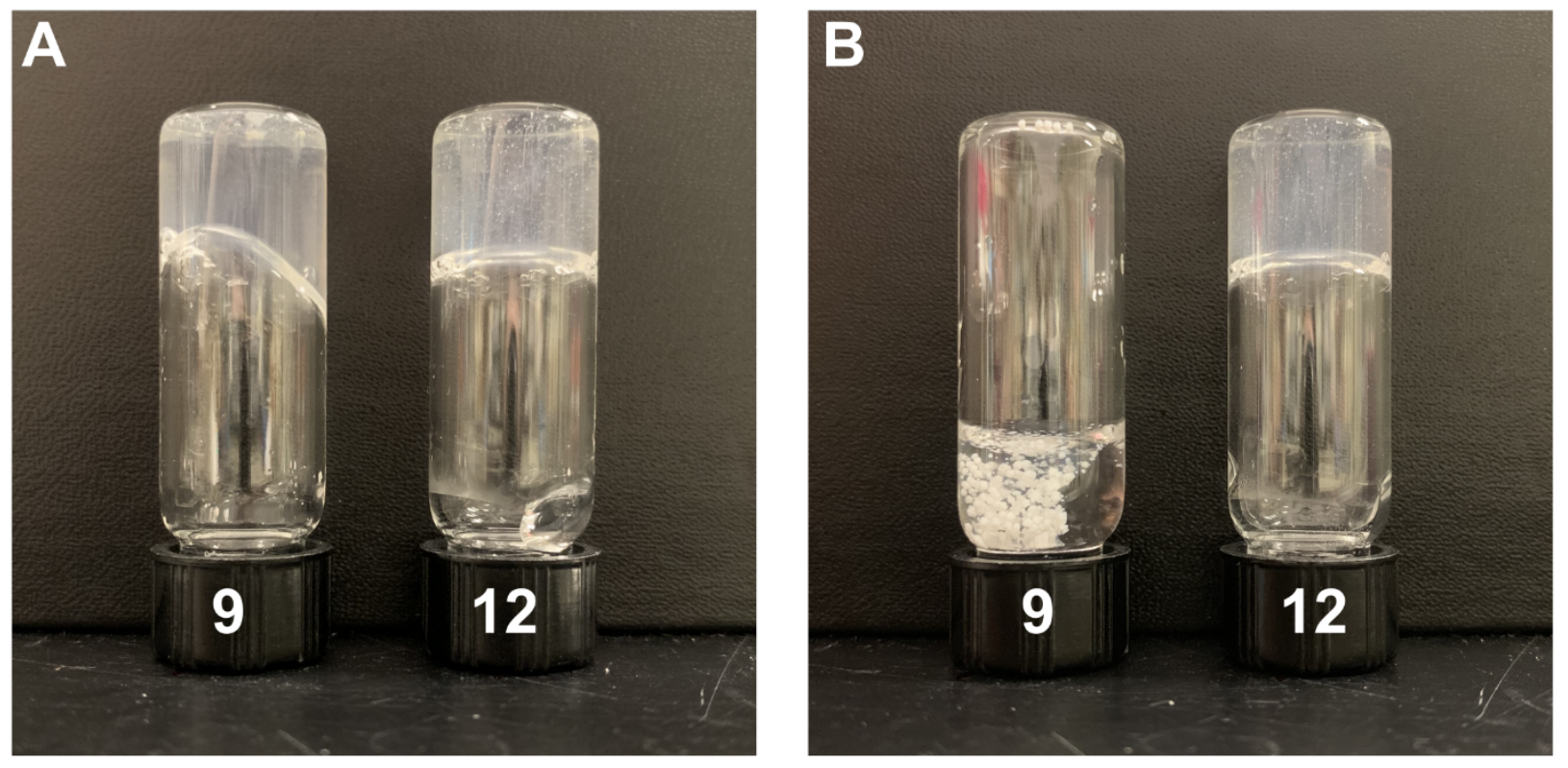

Figure S24. Digital images of hydrogels of compounds 9 and 12 made via the DMSO solvent switch method. (A) Image taken three hours after self-assembly was initiated for compounds 9 and 12. (B) Image taken six days after self-assembly was initiated for compounds 9 and $\mathbf{1 2}$. The hydrogel network of compound $\mathbf{9}$ has undergone precipitation and the gel has degraded.
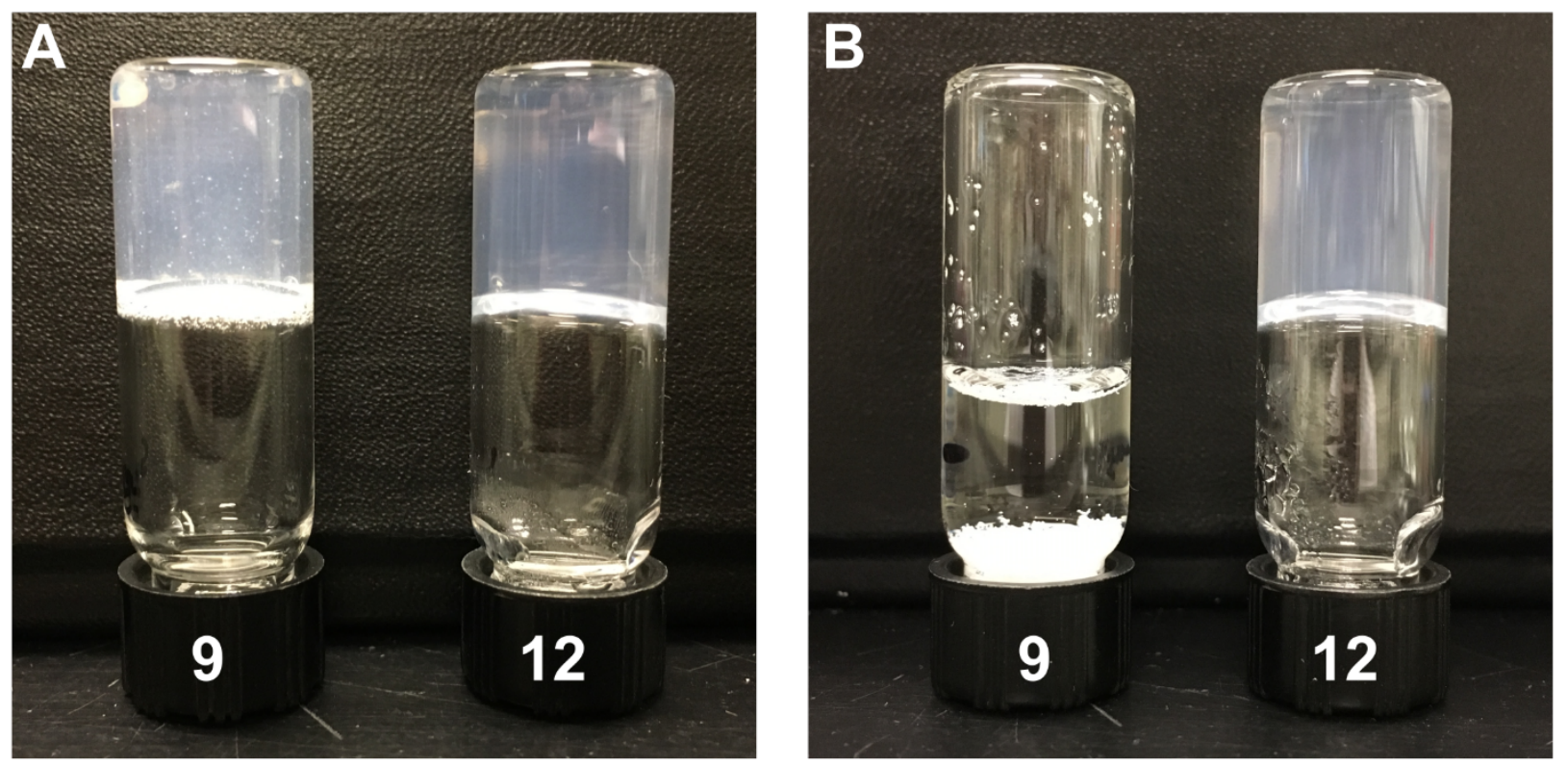

Figure S25. Digital images of hydrogels of compounds $\mathbf{9}$ and $\mathbf{1 2}$ made via the GdL pH switch method. (A) Image taken 24 hours after self-assembly was triggered for compounds 9 and 12. (B) Image taken 14 days after self-assembly was initiated for compounds 9 and 12. 


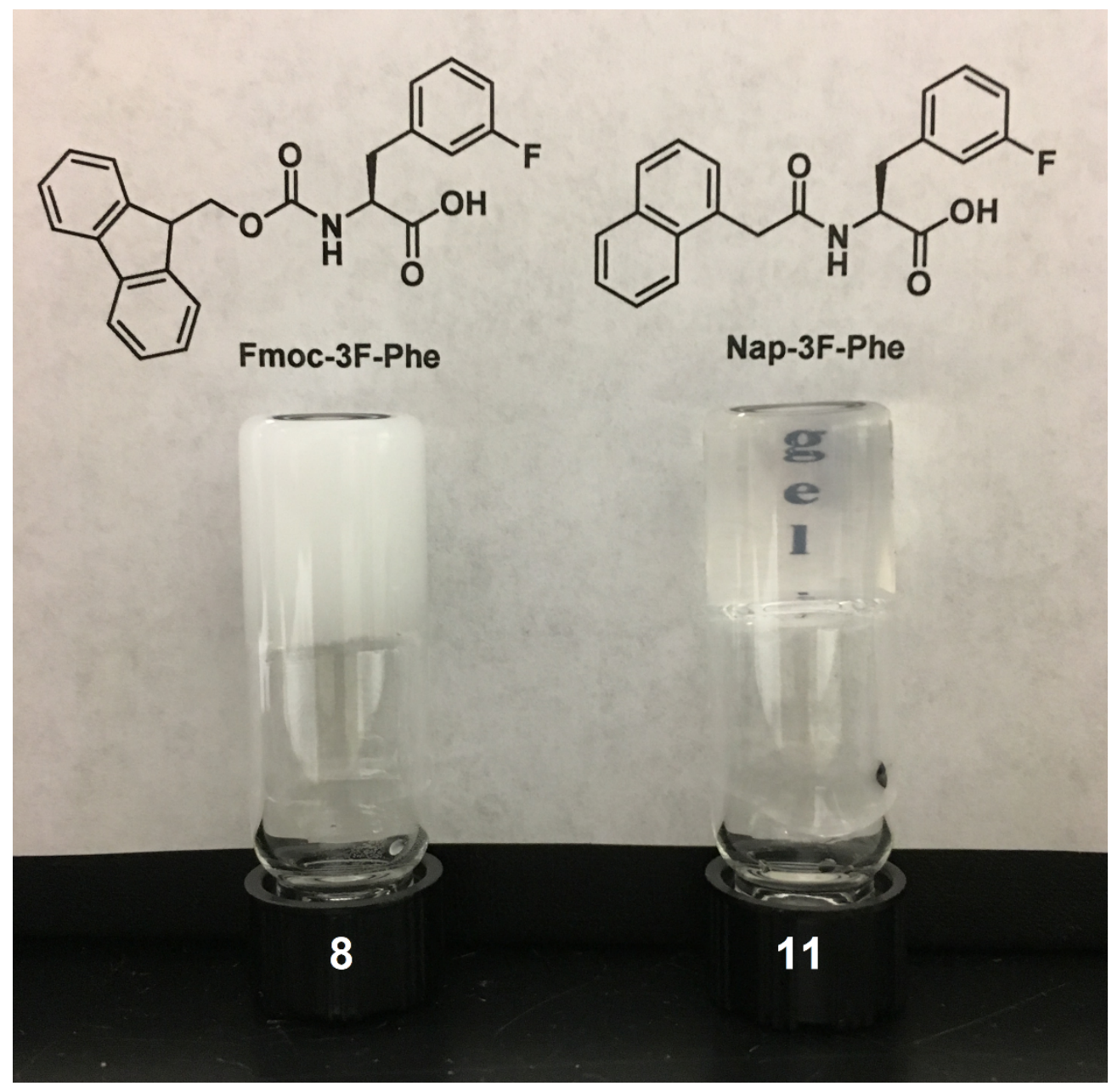

Figure S26. Digital image of hydrogels of compounds $\mathbf{8}$ and $\mathbf{1 1}$ made via the GdL pH switch method illustrating the optical transparency of Phe-derived gelators conjugated with 1-Nap compared to those modified with Fmoc. 